NBER WORKING PAPER SERIES

\title{
FINANCIAL AID PACKAGES AND COLLEGE ENROLLMENT DECISIONS: AN ECONOMETRIC CASE STUDY
}

\author{
David M. Linsenmeier \\ Harvey S. Rosen \\ Cecilia Elena Rouse \\ Working Paper 9228 \\ http://www.nber.org/papers/w9228
NATIONAL BUREAU OF ECONOMIC RESEARCH
1050 Massachusetts Avenue
Cambridge, MA 02138
September 2002

We have received useful suggestions from Orley Ashenfelter, Don Betterton, C. Anthony Broh, Melissa Clark, Susan Dynarski, Fred Hargadon, Bo Honoré, Jeffrey Kling, Nancy Malkiel, Robin Moscato, Miriam Platten, Mark Votruba, Till von Wachter, Diane Whitmore, and members of the Princeton University Labor Lunch, Princeton University Public Finance Working Group, and the NBER Higher Education Workshop. We are grateful to Princeton's Center for Economic Policy Studies and Industrial Relations Section for financial support. The views expressed herein are those of the authors and not necessarily those of the National Bureau of Economic Research.

(C) 2002 by David M. Linsenmeier, Harvey S. Rosen, and Cecilia Elena Rouse. All rights reserved. Short sections of text, not to exceed two paragraphs, may be quoted without explicit permission provided that full credit, including (C) notice, is given to the source. 
Financial Aid Packages and College Enrollment Decisions: An Econometric Case Study David M. Linsenmeier, Harvey S. Rosen, and Cecilia Elena Rouse

NBER Working Paper No. 9228

September 2002

JEL No. I20

\section{ABSTRACT}

We study the effects of a change in financial aid policy introduced by a Northeastern university in 1998. Prior to that time, the university's financial aid packages for low-income students consisted of grants, loans, and campus jobs. After the change, the entire loan portion of the package for low-income students was replaced with grants. We find the program increased the likelihood of matriculation by low-income students by about 3 percentage points, although the effect is not statistically significant. The effect among low-income minority students was between 8 and 10 percentage points and statistically significant at the 10 percent level.

David M. Linsenmeier

Department of Economics

Princeton University

Princeton, NJ 08544

davel@princeton.edu

Cecilia Elena Rouse

Education Research Section

Firestone Library

Princeton, NJ 08544

and NBER

rouse@princeton.edu
Harvey S. Rosen

Department of Economics

Princeton University

Princeton, NJ 08544

and NBER

hsr@princeton.edu 


\section{Introduction}

In recent decades, the average cost of attending a four-year college has risen substantially, from $\$ 9,539$ in 1988 to $\$ 12,282$ in 1998 (in 1999 constant dollars) [Digest of Education Statistics, 2000] ${ }^{1}$. This increase has engendered concerns that attending college is beyond the financial reach of many students. The public policy response has been to introduce or expand a variety of government grant and scholarship programs. ${ }^{2}$ At the same time, a number of colleges and universities have improved their own financial aid programs in order to attract low-income students. This can be done in two nonmutually exclusive ways. The first is to increase the amount of aid; the second is to alter the composition of the aid package, changing the mix of grants, loans, and jobs.

Although there is a substantial academic literature on the impact of tuition levels on enrollment decisions (see, e.g., Manski and Wise [1973], McPherson and Schapiro [1991a,b], Kane [1994], and Rouse [1994]), not much research has been done on the effects of different types of financial aid on student enrollment. The key result in the literature is that enrollment decisions are, in fact, sensitive to the amount of tuition. Further, Kane [1994] finds that the decision to enroll in college is sensitive to both tuition and the level of Pell Grants. The effects are roughly of equal magnitude and opposite sign, suggesting that net college cost (as opposed to "sticker price") is the relevant variable in the matriculation decision. ${ }^{3}$ A smaller literature has attempted to estimate the effect of college costs on enrollment at a particular institution. Hoenack [1971], Ehrenberg and Sherman [1984], and Moore, Studenmund and Slobko [1991] each

\footnotetext{
${ }^{1}$ All dollar values in this paper are in 1999 dollars unless otherwise specified.

${ }^{2}$ For example, during the 1990s Congress increased the level of Pell grants, made student loans more generous, and introduced college tax credits (Kane [1999]). In addition, there is growing interest in reducing the loan burden of low-income students by such measures as front-loading Pell grants.
} 
estimate the probability that a student accepts an offer at a particular school; they find that higher net college costs make students less likely to enroll at a particular institution. Additionally, Ehrenberg and Sherman find that the response is largest for minority students, middle to upper income students, and more scholastically able students (as measured by SAT scores).

A potential problem with many of these papers is that the data lack a source of variation in college costs or financial aid composition that is exogenous to student characteristics. College financial aid offers often depend on the characteristics of the student; students who are considered more desirable by the college administration may receive more generous offers. Hence, college costs and financial aid packages are likely correlated with student characteristics. As a result, in a regression of the attendance decision on net college cost, it is difficult to identify the independent effect of college cost. In particular, the coefficient on college cost may partially reflect the impact of unobserved characteristics of the student. In an attempt to address the selection problem, van der Klaauw [1996] uses a regression discontinuity approach to estimate that the financial aid offer has a significant effect on college enrollment. Dynarski [1999, 2000] uses the end of the Social Security Student Benefits program and the creation of the Hope Scholarship in Georgia as exogenous sources of variation and finds, in both cases, positive effects of grant aid on student enrollment in college. ${ }^{4}$

In this paper, we analyze the effect of grant aid on student matriculation at a major Northeastern university (hereinafter referred to as "NEU"). Like most selective

\footnotetext{
${ }^{3}$ See also Schwartz [1985] and Savoca [1991].

${ }^{4}$ Under the Social Security Student Benefits program, which ended in 1982, 18- to 22-year-old children of deceased, disabled or retired Social Security beneficiaries received substantial monthly payments while
} 
colleges, NEU administers its own financial aid program, and in this analysis we study a change in NEU's financial aid policy. Prior to 1998, NEU's financial aid package to low-income students included loans, scholarships, and jobs. ${ }^{5}$ Beginning with the class of 2002 (which entered NEU in September, 1998), the loan component for these students was entirely eliminated and replaced with grants. Because this change in the financial aid policy induced systematic variation in the financial aid packages of low-income students that is likely uncorrelated with other student characteristics, this exogenous policy variation allows more meaningful estimates of the effect of the form of financial aid on college enrollment. We implement a "difference-in-differences" estimator to study the impact of this policy change on the probability that admitted low-income students enroll at NEU. Our main finding is that converting loans to grants had no statistically discernible effect on the matriculation rate of low-income admits. However, there was a marginally significant positive impact on the likelihood of enrollment among low-income minority students.

The rest of the paper is organized as follows. Section II provides a description of the financial aid program at NEU, both before and after the 1998 change. Section III provides a theoretical framework for understanding the program's effect on matriculation. Section IV describes the primary data for our analysis. Some descriptive statistics and the econometric results are presented in Section V, along with a discussion of the interpretation and robustness of our results. Section VI concludes.

enrolled full-time in college. Under the Hope Scholarship program, all Georgia residents with at least a B average in high school can attend a public college in Georgia for free.

${ }^{5}$ Not all students who qualify for financial aid are considered low-income. The detailed definition of lowincome status is discussed below, in Section II. 


\section{Institutional Background}

In 1998 NEU announced that the loan component of the financial aid package of every low-income student would be replaced by grants. University officials identified two major reasons for this change. The first was to reduce the importance of financial barriers in the decision to apply to or attend the school, and the second was to ensure that a recent drop in the number of low-income students matriculating did not become a trend. Officials emphasized that this policy was not undertaken to lure students away from other institutions, but rather to fulfill NEU's commitment to provide adequate financial aid to all students.

When a student applies for aid, NEU first computes his or her "demonstrated need," which is the difference between the cost of college and NEU's estimate of the student's ability to pay based on his or her family's financial position. The student receives this amount of support in the form of a package that potentially consists of three components: grants, loans, and jobs. Grant aid includes funds from any source (federal Pell grants, university endowment funds, etc.) that are provided without expectation of repayment or any work done by the student. Loans must be repaid with interest, although the payments and accrual of interest may be deferred until some time after the student's graduation, and interest is charged at less than market rates. Job aid consists of a paid position at the university, usually made available through the financial aid or a related office. At NEU, such jobs usually require nine hours of work each week during the academic year.

These three forms of aid have different costs and values to both the college and the student. Jobs are relatively inexpensive for the university because the student 
performs services of value in return for the funds. Some student jobs are also subsidized by the federal work-study program, which pays part of a qualified student's wages. Loans are less expensive than grants for the loan provider, as they are repaid (even though the interest rate is usually low and the payments are often deferred for several years). To a student, grants are the most valuable, being essentially "free money." In contrast, the present discounted value of a dollar of loan aid is only about fifty cents. ${ }^{6}$

Financial aid offers for students admitted to NEU are calculated according to the following process. The financial aid staff begins by determining the student's family contribution (a function of the family's financial resources). If the family's calculated ability to pay is less than the cost of attending NEU, then the student qualifies for financial aid. In composing the financial aid package, the financial aid staff begins with a standard amount of job aid and a base loan amount; grants fill the remaining gap between the student's ability to pay and the cost of NEU. The final financial aid package is then adjusted by the financial aid staff where deemed appropriate. Because of this final adjustment, there is no straightforward algorithm that exactly determines each student's financial aid package.

The cost of attending NEU rose from $\$ 27,729$ in 1988 to $\$ 34,171$ in 2000 , and NEU's financial aid packages grew along with it. (All dollar figures in this paper are expressed in 1999 dollars unless otherwise specified.) In 1988, the standard financial aid package included $\$ 2,028$ in job aid, rising slightly to $\$ 2,109$ in 2000 . Over the same

\footnotetext{
${ }^{6}$ The precise value, of course, depends on factors such as the particular terms of the loan and the student's discount rate (McPherson and Schapiro [1991b], Feldstein [1992]).
} 
period, the base loan amount increased from $\$ 3,731$ to $\$ 4,063$, and the remaining grant component increased from a median of $\$ 11,865$ to $\$ 14,842 .^{7}$

The new policy announced in January 1998 made NEU more attractive to lowincome students by giving them grants in place of the loans they would have received under the old regime. Under the new policy, the loan component of these students' packages was completely eliminated and replaced with grants. That is, a low-income student who would have been expected to borrow $\$ 4,000$ per year was instead given an additional $\$ 4,000$ in grants for $1998-1999 .{ }^{8}$ The total amount of financial aid was not affected, only the composition.

Clearly, an important aspect of the process is how the financial aid office classifies students as "low-income." Before 1998, the financial aid office defined lowincome status based on expected parental contribution. ${ }^{9}$ If the student's parental contribution was less than $\$ 2,000$, he or she would likely be classified as low-income. Low-income students were asked to take smaller loans than other students $-\$ 500$ to \$2000 less for the poorest students in 1997, less than that in earlier years. Under the new policy, students are classified as low-income if their family income is less than the national median family income $-\$ 41,955$ for the class entering in $1998 .^{10}$

\footnotetext{
${ }^{7}$ The median is calculated among students receiving grant aid.

${ }^{8} \mathrm{NEU}$ made other changes to its financial aid policy for the class of 2002. For students whose family incomes are just above the low-income range, loans were reduced by smaller, graduated, amounts. In addition, for low- and middle-income students, family assets were redefined to include only a portion of housing equity. Because we lack adequate information on housing assets, we cannot fully incorporate these changes into our analysis. However, we do account for the effect of the middle-income change in Tables 4 and 6.

${ }^{9}$ The student's ability to pay is composed of two parts: the expected parental contribution and the contribution from the student's own resources (e.g., from summer jobs and external scholarships).

${ }^{10}$ This figure is the median among families with children under age 18 in 1996, the latest year for which data were available when the cutoff was set in late 1997 for students entering NEU in the fall of 1998. This is reported in nominal currency because the Financial Aid Office based its low-income classification on nominal dollars.
} 
NEU officials estimated that this new program would cost approximately $\$ 1.7$ million per year by the time it was fully phased-in, in fiscal year 2002. The goal of this paper is to determine whether this expenditure has increased the yield (percentage of admitted students enrolling) among low-income students, and if so, by how much.

A key question is whether NEU instituted other innovations that might affect yield rates at the same time that it replaced the loan component of financial aid packages with grants. In particular, were there any changes in outreach programs to high school students to encourage them to apply, or changes in strategies to convince accepted students to matriculate? We posed this question to the director of the admissions office and learned that no strikingly different recruitment strategies were used in recruiting the graduating classes of '02, '03, and '04 (the first three years of the new financial aid policy). Some new approaches to recruiting low-income students were introduced for the class of '05, but members of this and subsequent classes are not included in our analysis (see below). In short, we do not believe there were any concurrent changes in the activities undertaken by NEU's admissions office that would confound our efforts to isolate the impact of the change in financial aid policy.

\section{Theoretical Framework}

In this section we develop a simple two-period model of how NEU's change in financial aid policy might affect matriculation decisions. Suppose that a student admitted to NEU has the utility function $\mathrm{U}=\mathrm{U}(\mathrm{Y})$, where $\mathrm{Y}$ represents income after graduation. The student is risk averse, with $\mathrm{U}^{\prime}(\mathrm{Y})>0$ and $\mathrm{U}^{\prime \prime}(\mathrm{Y})<0$. In the first period, the student decides whether or not to enroll at NEU. In the second period, with probability $\mathrm{p}$ the 
student will receive a good job and earn income G, and with probability (1-p) she will get a bad job and earn B. For simplicity, assume that if the student enrolls at NEU then she must take out loans which require a payment of $\mathrm{L}$ in the second period. Before the policy change $\mathrm{L}$ is positive, and after the policy change $\mathrm{L}$ is zero for low-income students. If the student attends an alternative college, her expected utility is A, which is unaffected by the policy change at NEU (an assumption we assess, below).

The student chooses to attend NEU if the expected utility from attending NEU is greater than the expected utility from attending her alternative college. The expect utility of attending NEU is

$$
\mathrm{E}\left(\mathrm{U}_{\mathrm{NEU}}\right)=\mathrm{p} \mathrm{U}(\mathrm{G}-\mathrm{L})+(1-\mathrm{p}) \mathrm{U}(\mathrm{B}-\mathrm{L})
$$

The expected utility of the alternative, by assumption, is $E\left(U_{A}\right)=A$.

She attends NEU if

$$
\begin{gathered}
\theta=\mathrm{E}\left(\mathrm{U}_{\mathrm{NEU}}\right)-\mathrm{E}\left(\mathrm{U}_{\mathrm{A}}\right)>0 \\
\theta=\mathrm{p} \mathrm{U}(\mathrm{G}-\mathrm{L})+(1-\mathrm{p}) \mathrm{U}(\mathrm{B}-\mathrm{L})-\mathrm{A}>0
\end{gathered}
$$

where $\theta$ is the net benefit, in expected utility terms, of choosing NEU over the alternative.

To find the impact when loans are reduced by the policy change at NEU, we compute

$$
\delta \theta / \delta L=-p U^{\prime}(G-L)-(1-p) U^{\prime}(B-L)
$$

Since $\mathrm{U}^{\prime}(\mathrm{Y})>0$ for all $\mathrm{Y}, \delta \theta / \delta \mathrm{L}<0$. The policy change, which decreases $\mathrm{L}$, increases $\theta$, making NEU relatively more attractive than the alternative. 
An interesting question is whether some students would be more responsive to the loan-reduction program than others. In this model, the extent to which NEU becomes more attractive depends on $\mathrm{p}$ :

$$
\delta^{2} \theta / \delta L \delta p=U^{\prime}(B-L)-U^{\prime}(G-L)
$$

which is positive, since $\mathrm{U}^{\prime \prime}<0$ (decreasing marginal utility of income) implies that $\mathrm{U}^{\prime}(\mathrm{B}-$ $\mathrm{L})>\mathrm{U}^{\prime}(\mathrm{G}-\mathrm{L})$. If a student has a low $\mathrm{p}, \delta \theta / \delta \mathrm{L}$ is more negative, the student has a larger loss of utility from an increase in loans, and a given loan reduction has a larger effect on the relative attractiveness of NEU over an alternative. Thus, the model predicts that the program will have a relatively greater effect on matriculation at NEU for those students with relatively low a priori expectations of getting a good job. Equation (5) will prove useful in interpreting some of our results below.

\section{Data and Econometric Model}

A. $\quad \underline{\text { Data }}$

\section{1. $\quad$ Admissions Data}

Our primary data come from the administrative archives of NEU's Financial Aid Office. The database contains detailed financial aid and admissions information on each year's admitted students, including financial information such as family income and assets and the composition of their financial aid packages. We analyze data from the classes of 1992 through 2004 (who entered in 1988 through 2000). The data are proprietary and sensitive, as they contain detailed individual financial information on NEU's undergraduates and alumni. The archiving is done after the admissions process is complete but before the students actually begin classes. 
We begin with 25,958 individual students' records and drop 1,433 observations with missing or ambiguous information. ${ }^{11}$ Additionally, because the program is particularly targeted at American students and because international students' financial indicators are relatively difficult to interpret, for most of the analysis we focus our attention on U.S. citizens, reducing the sample by an additional 2,465 records. Another 8,359 admitted students are excluded from the primary analysis because they applied for early decision or early action. ${ }^{12}$ These students choose to commit to, or at least focus on, NEU before they receive financial aid offers. Their enrollment decisions, therefore, are likely less sensitive to financial aid, and it is not appropriate to analyze them along with regular admission applicants. More importantly, early decision application binds the student to attend if accepted, so there is no choice to model conditional on admission.

\section{2. $\quad$ SAT Test-taker Data}

As a secondary source of information, we also analyze data on SAT test-takers from the College Board. The idea is to assess whether NEU's change in financial aid policy affected the applicant pool, because if the applicant pool changed in such a way as to affect yield rates, it would cloud the interpretation of our results. We have data on students projected by the College Board to have graduated from high school between 1994 and 2001. The sample includes all African-American and Hispanic SAT takers, all test takers from California and Texas, and a 25 percent sample of non-Black, nonHispanic test takers residing outside of California and Texas. These data contain limited

\footnotetext{
${ }^{11}$ In most of these cases, there was a problem in the coding of the student's enrollment decision.

12 NEU switched from a non-binding "early action" policy to a binding "early decision" policy beginning with the class of 2000 .
} 
information on personal characteristics, including crude measures of family income, ${ }^{13}$ parental education, and participation in extracurricular activities, and academic achievement (as measured by the student's math and verbal SAT scores). Most importantly, the data contain information on up to 20 (for the years 1994-1998) and 30 (for the years following 1998) institutions to which the student requested the SAT scores be sent. ${ }^{14}$ We characterize a student as having interest in applying to NEU if she indicates that her SAT scores should be sent to NEU. While this indicator is not a perfect measure of who eventually applies to NEU, we believe that it is highly correlated. We assume that test-takers who took the SAT after January, 1998 (when the policy change was announced) were "exposed" to the change in financial aid policy and constitute the treatment group; students who took the test before January 1998 form the comparison group. ${ }^{15}$

Using these data we created a sample analogous to the admissions data from NEU. The sample includes only U.S. citizens who were attending a domestic school at the time of registration for the SAT and who were not missing information on their race or ethnicity. In addition, we dropped students who were missing test scores (these students registered for the test but did not actually take it), and those who did not indicate

\footnotetext{
${ }^{13}$ Family income is reported in ranges. We use midpoints of these ranges to code students as low-income following the same definition as in the NEU admissions data: family income below the national median.

${ }^{14}$ We include a dummy variable indicating whether the student had the option to request 30 institutions (i.e., that the student took the SAT in 1999 or later). The inclusion of this dummy variable does not change the results since most students list fewer than 20 institutions.

${ }^{15}$ There are other possible criteria for identifying students potentially affected by the change in financial aid policy. The first is whether the student was likely to have graduated from high school after the 1998 policy change (i.e., graduated from high school in 1999 or afterwards) or using the date that the student submitted his or her questionnaire to the College Board. The results using these alternative measures are quite similar. In addition, we drop 66,160 students who took the SAT in 2001 since there are only data for the first few months of that year.
} 
any school to receive their scores. Our final analysis sample includes 3,031,573 individuals; Appendix Table 1 provides descriptive statistics on these data.

\section{B. Econometric Model}

We estimate the impact of the change in financial aid policy on admitted lowincome students' likelihood of enrolling at NEU by modeling the individual student's decision to accept NEU's admissions offer as a conventional probit model:

$$
\mathrm{E}_{\mathrm{it}}=\mathrm{F}\left[\alpha+\mathrm{P}_{\mathrm{t}} \beta_{1}+\mathrm{LI}_{\mathrm{it}} \beta_{2}+\left(\mathrm{P}_{\mathrm{t}} * \mathrm{LI}_{\mathrm{it}}\right) \beta_{3}+\mathrm{X}_{\mathrm{it}} \gamma\right]
$$

where $E_{i t}$ is the probability that student $i$ chooses to enroll at NEU in year t, F[ ] is the cumulative normal distribution, $\mathrm{X}_{\mathrm{it}}$ is a vector of student characteristics (described in the next section), $\mathrm{P}_{\mathrm{t}}$ is a binary variable that equals 1 if the student applied after the 1998 change in financial aid (i.e., it equals one for all students in the classes of 2002, 2003, and 2004), $\mathrm{LI}_{\mathrm{it}}$ is a binary variable that equals 1 if the student is classified as low-income, and $\beta_{1}, \beta_{2}, \beta_{3}, \gamma$ and $\alpha$ are parameters to be estimated. To allow comparisons between lowincome students before and after the policy change, we reclassify students from all classes as low-income according to the definition adopted by the financial aid office at the time of the policy change. That is, we classify students as low-income if their family income was below the national median for families with children under 18 in the year before they applied.

The coefficient $\beta_{1}$ reflects the change in probability that non low-income students in the classes of 2002, 2003, and 2004 (those that applied after the change in financial aid) enrolled at NEU relative to those who applied earlier. As such, it measures the impact of all aspects of the post-program environment that might have affected the 
probability of accepting an offer of admission. The coefficient $\beta_{2}$ reflects the difference in probability of enrolling at NEU between students who were classified as low-income and those who were not, for all classes. The coefficient $\beta_{3}$, on the interaction between $P_{t}$ and $\mathrm{LI}_{\mathrm{it}}$, reflects the incremental effect on the probability of accepting admission at NEU for low-income students after the change in financial aid took effect. It is, therefore, our coefficient of interest -- the difference-in-differences estimator for this program. The identifying assumption is that the change in financial aid policy did not affect the enrollment rates of non-low-income students.

The specification in equation (6) implicitly assumes that the effect of the new program was the same for each class. We also estimate an alternative specification in which we allow the effect of the program to vary by class:

$$
E_{i t}=F\left[\alpha^{\prime}+C_{t} \beta_{1 t}+L_{i t} \beta_{2}{ }^{\prime}+\left(C_{t}^{*}{ }^{*} I_{i t}\right) \beta_{3 t}+X_{i t} \gamma^{\prime}\right]
$$

where $C_{t}$ is a set of binary variables that take a value of one if a student is in a particular class, and zero otherwise (the omitted class is 1999), and $C_{t} * L_{i t}$ is a set of interactions between the class effects and a dichotomous variable indicating whether the student was low-income, and the other notation is as defined above. Each of these interactions shows, for the respective class, the difference in the probability of acceptance between lowincome students in that class and the other students, ceteris paribus. This specification contains no single regression coefficient that summarizes the effect of the program. We therefore estimate the effect of the program by computing the average of the coefficients of the interaction terms $\left(\beta_{3 t}\right)$ during the program period (i.e., for the classes of 2002 , 
2003, and 2004), and compare it to the average for the classes in the years before the program. ${ }^{16}$ The difference between the averages is the net program effect.

\section{Results}

\section{A. Descriptive Statistics}

Table 1 exhibits mean student characteristics over the entire sample period. These statistics apply to admitted U.S. citizens who applied regular decision, not early action or early decision. We present statistics on income status, financial aid status, sex, census division of residence, ethnicity, whether the student was a recruited athlete, and the student's academic and non-academic ratings as assigned by the admissions office. The academic rating was based on factors such as high school grades, SAT scores, prior experience with graduates of the same high school, and teacher recommendations. An academic rating of A was given to students who were best-prepared academically (e.g., with high grades and high SAT scores); an academic rating of E was given to the least prepared students. The non-academic rating was determined by a variety of attributes such as leadership, athletic or artistic ability, and volunteer work. The non-academic ratings also ranged from $\mathrm{A}$ to $\mathrm{E}$. We report means of the various student characteristics broken down by whether the student was low-income (again retroactively applying the post-change definition) and by whether the student enrolled.

Ninety-eight percent of the admitted low-income students in our analysis sample were awarded financial aid, ${ }^{17}$ compared to only 43 percent of non-low-income students. Further, relative to high-income students, low-income students had on average lower

\footnotetext{
${ }^{16}$ Weighting this average by sample sizes in each year has no substantial effect on the results.

${ }^{17}$ The remaining two percent of students had substantial assets despite low income.
} 
admissions ratings (both academic and non-academic), were less likely to be athletes and alumni children, and were more likely to be minorities. (Throughout our analysis, we classify students as minority if they identified themselves as African-American, Hispanic, or Native American. We do not classify Asian students as minority.) The fraction of minority students in our sample is quite high, approximately one-fourth of the overall sample and increasing to nearly one-third by the end of the analysis period, as shown in Table 2. This is higher than the overall fraction of minority students at NEU, as minority students were relatively more likely to apply regular decision, and hence to be included in our analysis sample.

Table 2 contains time series data on key characteristics of NEU students in our analysis sample. Since the early 1990s, the percentage of admitted students who were low-income has ranged from about 8 to 12 percent; the percentage of enrolled students who were low-income has ranged from 7 to 14 percent. ${ }^{18}$ The fraction of admitted and enrolled students receiving financial aid has ranged between 45 and 58 percent. Over time, the percentages of females and minorities have increased. Both the academic and nonacademic ratings of the classes have improved. ${ }^{19}$ Further, smaller proportions of the class have been recruited athletes.

Aggregate yield rate data from the classes of 1992 through 2004 are summarized in Table 3. The first column indicates that yield rates at NEU increased over time, starting at about 55 percent in the early 1990s and ending at 72 percent for the class of 2004. As noted in Section IV, we focus on students who went through the regular admission process. Since early decision students were committed to enroll, and early

\footnotetext{
${ }^{18}$ These calculations use the national-median based low-income definition to all classes, retroactively for those earlier than the class of 2002.
} 
action students were very likely to do so, the yield rates for students admitted under regular admission were lower than those for all admitted students, and although they also increased, the trend was been at a substantially slower rate (from 47 percent in the class of 1992 to 53 percent in the class of 2004).

The next two columns show the yield rates by income status, again imposing the 1998 definition of "low-income" on all classes. For convenience, these rates are graphed in the upper panel of Figure 1. At the beginning of the period, the yield rate for lowincome students was below that for students who were not, but by the end of the sample period, the situation was reversed. Enrollments of African-American, Hispanic, and Native American ("minority") students have been a matter of special concern at NEU and a number of other institutions, so in the last two columns (and the lower panel of Figure 1) we show yield rates among minorities.

Figure 1 suggests that the difference in yield rates between low-income and notlow-income students has widened since the change in the financial aid program, suggesting that the change in financial aid composition had a sizeable impact on the matriculation of low-income students. However, the figure also highlights some difficulties with this conclusion. First, note that the yield rates for classes in the early 1990s were quite a bit lower than those for the last three classes, the "treatment" group. Hence, if we visually compare the last three classes with their predecessors as a group, it appears that the yield rates increased during the program period. On the other hand, suppose that we choose to make the comparison group only the four classes before the program was introduced. In this case, the answer from visual inspection is no longer quite so clear.

\footnotetext{
${ }^{19}$ The nonacademic ratings for the class of 1992 are on a different scale than other classes.
} 
In the same way, we cannot know whether the unusually low yield among lowincome students for the class of 2001 reflected a permanent change in the yield rates that would have continued had NEU not changed its financial aid policy, or whether it was a transitory change. If the yield for the class of 2001 reflected a permanent change, then it makes sense to use it as a base from which to evaluate the financial aid program. In contrast, if the yield for the class of 2001 reflected a transitory change, then its inclusion in the analysis will artificially inflate the estimated impact of the program.

One possibility is that the patterns in Figure 1 are driven by changes in student characteristics over time. To investigate this issue, in Figure 2 we show the time series in yield rates adjusted for student characteristics. (The adjustments are based on a probit regression that controls for race, gender, total size of financial aid award, alumni child, region of permanent residence, recruited athlete, and both academic and nonacademic rankings for admission. $)^{20}$ While the regression-adjusted variation in yield rates is somewhat smaller than the unadjusted, the patterns do not change enough to resolve the ambiguities just discussed. In short, the time series pattern of yield rates raises the possibility that our substantive results may be sensitive to the choice of comparison classes. Our statistical analysis explicitly takes this possibility into account.

Another concern is that the yield rates among different income groups may have moved differently over time for reasons that have nothing to do with the financial aid practices of NEU. Of course, we cannot know what would have happened at NEU if it had not changed its policy. However, we can compare the time series on yield rates at NEU to the pattern at several similar universities in the Northeast. The Consortium on Financing Higher Education (COFHE) provided us with data on overall yield rates and 
yield rates among minorities at a group of similar universities; the COFHE data do not allow us to disaggregate other schools' yield rates by students' incomes. ${ }^{21}$ The yield rate data for these schools are summarized in Figure 3. Note that the yield data for NEU in this figure differ from those in previous figures. In order to make the two panels of Figure 3 fully comparable, we use the COFHE data for NEU as well, re-introducing the early admissions and international students to the sample. Figure 3 suggests that NEU's peer institutions did not experience the dip in the yield rate that occurred in NEU's class of 2001. This is consistent with the notion that the dip at NEU was, in fact, transitory, for if more fundamental forces were at work, NEU's peer institutions would likely have experienced a similar phenomenon.

\section{B. Multivariate Analysis}

\section{Overall Results}

Column (1) of Table 4 shows the results from estimating equation (6) without individual covariates $\left(\mathrm{X}_{\mathrm{it}}\right)$. The coefficient on the program variable indicates that during the period it has been in effect, the yield rate for non-low-income students was 6.6 percentage points higher than previously, an increase that is statistically significant at the 5 percent level. The coefficient on the interaction term indicates that the probability of a low-income student accepting the offer was 4.7 percentage points higher than that, although the difference is not statistically significant. Hence, in this basic model, we cannot detect a statistically discernible effect of the program on the yield of low-income students.

\footnotetext{
${ }^{20}$ This regression is reported as column (4) of Table 4.

${ }^{21}$ For consistency we have again excluded Asians from our definition of minority.
} 
As shown in Table 2, the composition of the admitted students changed substantially during the program period. Thus, in column (2) of Table 4 we control for a variety of individual characteristics. All of the variables are dichotomous and familiar from Table 1 except for the student's financial aid award, which reflects the value (in 1999 dollars) of the student's total financial aid from all sources. Controlling for the size of the package allows us to focus on the effect of the composition of the package. ${ }^{22}$ Women were 2.6 percentage points less likely to accept an offer than men; alumni children were 15.5 percentage points more likely than their non-alumni counterparts to do so. As both academic and nonacademic ratings increased, the probability of accepting an offer fell. Recruited athletes were 8.4 percentage points more likely to accept an admissions offer; minority students were less likely to accept an offer than were nonminorities. $^{23}$ The difference-in-differences estimate of the program effect, $\beta_{3}$ from equation (6), is smaller when the covariates are taken into account, 0.020 versus 0.047 from column (1), and is still not statistically different from zero.

An important assumption in equation (6) is that the non-low-income group was essentially homogeneous with respect to this program. However, students whose family's incomes fell within a small range above the national median income also had their loans reduced, but not to zero. It might be inappropriate to include these students in the comparison group. Hence, we re-estimated equation (6) including on the right-hand side an indicator variable and an interaction with the program years for students whose

\footnotetext{
${ }^{22}$ If we use expected family contribution to control for family financial resources, we obtain substantially similar results.

${ }^{23}$ We have also estimated specifications in which we interact academic rating with other characteristics (such as race, whether athlete or child of alumni) with substantively similar results.
} 
incomes were greater than the national median but less than $\$ 57,000$ (in 1996 dollars). ${ }^{24}$ As shown in column (3) of Table 4, the net program effect is essentially unchanged. Thus, our results appear robust to whether or not middle-income students are included in the comparison group.

As noted above, the specification in equation (6) also implicitly assumes that the effect of the new program was exactly the same for each class. In column (4) of Table 4 we allow the effect for low-income students to vary by class as described in equation (7). The second figure in the column, the net program effect, is 0.023 with a standard error of 0.039. Again, this is essentially the same as the estimate of the program effect in column (2). Hence, allowing for separate class effects has little impact on our assessment of the impact of the program. We also note that the coefficients on the other covariates are barely affected.

Beginning with the class of 2000 , two years before the financial aid policy change, NEU switched from a non-binding early action program to a binding earlydecision program. If this change affected the composition of the regular-decision body of students, one might be concerned that the exclusion of early admission students from our analysis biases our results. In column (5) of Table 4 we reintroduce the early applicants from all classes into our analysis and add controls for whether the student applied early action/decision and whether the university followed an early action or early decision policy in that year. The coefficient of interest becomes somewhat smaller, and remains insignificantly different from zero (as well as insignificantly different from the previous estimates). The estimated program effect falls because the indicator for early decision

\footnotetext{
${ }^{24} \$ 57,000$ is the cutoff that the financial aid office used in the first year of the program.
} 
years (the classes of 2000-2004) captures some of the recent rise in yields. We conclude that the change in early admission policy does not significantly affect our results.

\section{Alternative Comparison Classes}

The models of Table 4 are estimated using the data for every class available to us. However, as noted above, including all previous classes in the comparison group may be inappropriate. In particular, the decision-making process of students admitted in the early years of our sample might have been quite different from those of the students admitted since 1998, perhaps because of differences in unobservable characteristics. An additional concern mentioned earlier is that the yield rate among low-income students in the year just prior to the adoption of the program may have been transitorily low.

Because we have no compelling a priori reasons to view some years as more suitable for inclusion in the comparison group than others, we estimate the model with several different comparison groups. Table 5 shows the outcomes when we exclude the class of 2001 (column (1)), the classes of 2000 and 2001 (column (2)), all classes before 1997 (column (3)), and all classes before 1997 as well as 2000 and 2001 (column (4)).

As before, we focus on the coefficient on the interaction of the program and lowincome dichotomous variables. The overall results are insensitive to the choice of years to include. The point estimates of the program effect range from 1.1 to 3.4 percentage points, in the same ballpark as those in Table 4, and also are not statistically significant.

\section{Comparisons with Peer Institutions}


Another way to gauge the impact of NEU's financial policy is to make some comparisons with yield rates at its peer institutions. If there were no changes in NEU's yield rates relative to those of its peers, it would be consistent with our finding that the program had a small effect (although other explanations, discussed in Section 5 below, are also possible). To implement this idea, we did the following calculations. We computed the change in yield rates at the peer institutions before and after the introduction of NEU's program. We then subtracted this figure from the comparable change in NEU's yield rate. This difference-in-differences was 3.9 percentage points with a standard error of 3.2 percentage points. The estimate is not statistically significant, suggesting that the program had only a small effect at NEU.

In short, the finding that the program has no significant effect is robust to alternative specifications of the comparison group and alternative data sources.

\section{Effects by Race and Ethnicity}

Much of the discussion of financial aid packages for low-income students has focused on recruiting minorities. In this context, an important question is whether minorities are similar to the sample as a whole with respect to their responsiveness to changes in financial aid packages. Thus, we estimate the models from Table 4 with the sample restricted to minority students. This analysis compares the change in yield among low-income minorities to the change in yield among non-low-income minorities - we look for an effect of the program by low-income status within the minority population, not for an effect of the program on minorities as a group. ${ }^{25}$

\footnotetext{
${ }^{25}$ Twenty-three percent of minority students were low-income, higher than the 10 percent of the overall sample, but still a relatively small fraction. As a result, the program did not have any significant effect on
} 
The results are presented in Table 6. The key finding is that the program effect was between 8 and 10 percentage points, and that this effect is significant at about the 10 percent level. This is a large effect relative to the base yield of 40 percent for minorities before the class of 2002. In the specification that does not control for ethnic differences within the minority sample (column (2)), the significance level is 0.079 ; when we include dichotomous variables for Hispanic and Native American origins, the significance level is 0.106. As in column (3) of Table 4, column (4) shows that excluding middle-income students from the control group does not affect our coefficient of interest. Including the early admissions students, as in column (5) of Table 4, the significance level improves to better than $5 \%$.

As noted above, we have COFHE data on minority yield rates from several of NEU's peer institutions. As a second approach, we used these data to investigate how the minority yield rate changed at NEU relative to its peers. The difference-in-differences estimate is 5.5 percentage points with a standard error of 2.0 percentage points, an estimate that is significant at the $10 \%$ level. Thus, yield rates among minorities increased at NEU relative to its peer institutions after the program was introduced. This result is consistent with our findings based on NEU data alone.

We conclude that, on average, the program had a larger impact on low-income minorities - the point estimate is more than twice that for the entire sample, while its standard error is not much bigger. ${ }^{26}$ This is consistent with Jackson [1990], who, using an approach rather different from ours, found that in the decision to attend a college

the matriculation of minorities as a group relative to non-minorities (since over three-fourths of minorities were unaffected by the policy change). 
African-Americans respond positively to grants but not significantly to loans, and that African-Americans are about twice as responsive to grants as whites. ${ }^{27}$

\section{Discussion}

Why didn't NEU's change from loans to grants have a statistically discernable impact on the overall yield rate among low-income applicants, as we would have expected given equation (4)? One possibility is that admitted students were not fully aware of the program. However, the program did have a significant (at the 10 percent level) effect among minorities, and we have no reason to believe that minorities were better informed about the program. Additionally, even if students were not aware of the program when they decided to apply, they usually received financial aid details at the same time as the admission offer, so they should have known how the program affected them at the time they made their enrollment decisions.

Second, in our theoretical framework and interpretation of the results, we implicitly assume that NEU's peer institutions did not also change their financial aid policies in response to NEU's policy change. However, it is possible that we do not find an overall effect of the financial aid change on NEU's yield rate because peer institutions effectively mimicked NEU's new financial aid policy. We can say definitively that no peer institution officially announced a change in its policy in response to NEU. While

\footnotetext{
${ }^{26}$ Along the lines of Table 5, we checked the robustness of this finding to the inclusion of various classes. The effect is not very sensitive to these changes. To the extent there is a change, the impact becomes larger when we exclude the earlier classes.

${ }^{27}$ There are substantial differences between Jackson's study and our own. His estimates are based on a sample of applicants to all colleges (High School and Beyond) as opposed to applicants to a single college. Further, Jackson models the probability of attending college as a function of the presence of loans or grants as opposed to examining a change in regime from loans to grants. Also, Jackson estimates separate effects for blacks and Hispanics. We do not attempt to estimate separate effects because the number of Hispanics
} 
there is some anecdotal evidence that some institutions responded in an ad hoc manner, it is not clear whether or not these responses amounted to a systematic change in their programs.

Additional data provided by COFHE allow us to approach this issue more systematically. Figure 4 shows the average grant aid received by grant recipients at the same set of other Northeastern universities used in Figure $3{ }^{28}$ Had these other universities responded to NEU's financial aid policy change, their grant aid would have increased for the classes of 2002 and 2003. However, average grant aid at the peer institutions continued to follow its existing trend through this period. ${ }^{29}$ In addition, it is evident that NEU provided slightly less grant aid than its peers until the class of 2001, but provided more grant aid for all subsequent classes (thereby surpassing its peer institutions at exactly the time it introduced its low-income loan reduction program). These data provide further support for the assumption that NEU's peer institutions did not unofficially adopt NEU's financial aid policy. We also note that the fact that we estimate an effect for minority students suggests, at a minimum, that peer institutions did not fully respond.

Third, the change in financial aid (loan replacements of approximately $\$ 4,000$ per year) was fairly small relative to the average financial aid package of low-income students $-\$ 25,734$, of which an average of about $\$ 20,000$ would have been grants in the

is low. However, the estimates computed using only the sample of African-Americans are not substantially different from those that include Hispanics and Native Americans as well.

${ }^{28}$ We would have preferred to analyze average grant aid among low-income grant recipients. Unfortunately, no such data are available. Unlike the administrative data from NEU, these data show the actual award made, rather than the initial offer.

${ }^{29}$ An examination of the data institution by institution shows that this pattern holds for most of them individually as well as in aggregate. To maintain confidentiality, we do not display these results. There is one school which may have increased its grant aid for the class of 2003. However, this is the year in which 
absence of the loan-replacement program (the remainder being jobs). Perhaps this incremental change was too small to have had a detectable effect on enrollment decisions. Additionally, the underlying elasticity may be small. The combination of a small treatment and a small elasticity may have made the program effect too small to estimate precisely, particularly given the inherent noisiness of the process.

In this context, it is useful to compare our results to other estimates of the effect of financial aid on college attendance. Analyzing enrollment patterns at another "east coast college," van der Klaauw (2001) estimates that low-income students have an enrollment elasticity with respect to college grants of 0.86 . Table 7 , below, shows the predicted effect of NEU's financial aid policy change using van der Klaauw's estimate of the behavioral parameter. The perceived equivalent increase in total aid corresponding to a shift from loans to grants is hard to calculate, so we report a range of values: loans valued at one-half, one-third, and one-quarter of the face value. For example, consider the implications of van der Klaauw's estimated elasticity of 0.86 assuming (a) NEU's base yield among pre-program low-income admits is $50 \%$, (b) the pre-program base grant is $\$ 20,000$, and (c) the $\$ 4,000$ shift from loans to grants is valued by students at $\$ 2,000$ (on the high side of the previous literature). In this case, the predicted effect on yield rates is an increase of 4.3 percentage points. ${ }^{30}$ This is not significantly different from our estimated effect, from Table 4, column (3), of 2.3 percentage points with a standard error of 3.8 percentage points.

NEU's low-income yield showed the largest increase. If, in fact, a competitor increased its low-income grant aid in that year, it does not seem to have greatly impacted NEU's yield. 
Table 7

Predicted Effect of NEU's Policy Change Using van der Klaauw's Estimated Effects of Financial Aid on College Attendance

\begin{tabular}{cc}
\hline \hline \multirow{2}{*}{$\begin{array}{c}\text { Student values } \$ 1.00 \\
\text { of loans at }\end{array}$} & $\begin{array}{c}\text { Predicted Percentage Point Change in NEU's Low-Income Yield } \\
\text { Rate }\end{array}$ \\
\cline { 2 - 2 } & [elasticity $=0.86$ ] \\
\hline 0.50 & 4.3 \\
0.33 & 5.7 \\
0.25 & 8.6 \\
\hline \hline
\end{tabular}

In short, while it is possible that NEU's program had no effect on overall matriculation, we cannot reject the possibility that it had an impact similar to that found in previous analyses of enrollment decisions.

A question remains, however, why the program appears to have had a larger effect on the matriculation of minority applicants. One possibility is that the result is attributable to economic resource differences, since family financial status is so highly correlated with race and ethnicity. For three reasons, however, we do not believe that family resources are the primary explanation for the differences by minority status. First, our model controls for the total size of the financial aid package, which, as observed above, is a one-dimensional index of a family's overall financial position. Second, the minorities affected by the loan-replacement program are not actually much poorer than the whites so affected. Among low-income minority admits, the mean family income was $\$ 24,177$, only ten percent less than the mean among low-income whites of $\$ 26,836$. Plotting the income densities (not shown) reveals that the distributions are similar as well. Third, recall that the basis of our estimates is a difference-in-differences comparison between non-low-income and low-income students, within racial/ethnic groups. Among

\footnotetext{
${ }^{30}$ The calculation is as follows. By definition, if $\mathrm{Y}$ is the yield and $\mathrm{A}$ is the value of the aid package to the student, the elasticity is $(\Delta \mathrm{Y} / \mathrm{Y}) *(\mathrm{~A} / \Delta \mathrm{A})$. Substituting into this expression, $0.86=(\Delta \mathrm{Y} / 0.5) *$
} 
the non-low-income students in our analysis sample who reported family income, the mean income was $\$ 95,321$ for minorities and $\$ 109,514$ for non-minorities. ${ }^{31}$ Thus, the difference in average incomes between low-income and non-low-income whites and Asians is greater than the corresponding figure for minorities. If anything, this would tend to bias our estimates towards finding a smaller effect among minorities. As a result, we do not believe that a difference in resources explains the larger effect among minorities.

A second explanation for why the policy change had a larger impact on minority students is that the pool of applicants from which NEU admitted students may have changed after the new financial aid policies were instituted. As noted in Section II, NEU's admissions office reports that it did not change its recruitment strategies in the first three years after the policy change. Nevertheless, the change in financial aid policy may have induced some students who previously would not have considered NEU to apply. If these students were more inclined to choose to enroll at NEU conditional on acceptance (perhaps due to more limited alternative college options), then it is possible that changes in the characteristics of the applicant pool led to changes in the admitted pool, which led to changes in the yield rates.

We address this possibility using data from the College Board on SAT test takers. As discussed earlier, we model the student's decision to have his or her SAT scores sent to NEU using a model analogous to that in equation (6). Those who took the SAT after January, 1998 are considered to have been potentially affected by the policy change, while those who took the SAT before then are part of the comparison group. The results

$(\$ 20,000 / \$ 2,000)$. Solving, $\Delta \mathrm{Y}=0.043$. 
are presented in Table 8. Overall, approximately 2.2 percent of SAT takers request to have their scores sent to NEU. ${ }^{32}$ Without controlling for other covariates (column (1)), low-income students who took the SAT after the announcement of the policy change were no more likely to express interest in NEU than low-income students who took the test earlier (the coefficient estimate is 0.003 percentage points with a p-value of 0.95 ). Once one controls for student characteristics, as shown in column (2), low-income students were 0.051 percentage points more likely to express interest in NEU after the announcement of the policy change. This increase is a relatively small 2.3 percent of the overall likelihood that a student expresses interest in NEU, although the effect is statistically significant at the 5 percent level. The story for minority applicants, however, is quite different as shown in columns (3) and (4). Low-income minority students who took the SAT after the announcement were less likely to express interest in NEU, although the effect essentially disappears once one controls for student characteristics.

These results suggest that among low-income students, overall, there may have been a small increase in interest in applying to NEU. However, there was no detectable effect among minority applicants suggesting that a change in the applicant pool is unlikely to explain the results in Table 6.

A more compelling explanation for the greater impact among minorities is based on differing perceptions between minorities and non-minorities about the burden of financing college through loans. Such differences may be due to greater uncertainty

\footnotetext{
${ }^{31}$ The corresponding medians are $\$ 81,449$ and $\$ 97,317$, indicating that the difference in means is not driven only by a small number of very high-income families.

32 Appendix Figure 1 shows the percentage of students expressing interest in NEU, by the year they took the SAT test.
} 
among minorities about the future returns to college education, and hence ability to repay loans. In this context, recall the result of our model in Section III,

$$
\delta^{2} \theta / \delta L \delta p=U^{\prime}(B-L)-U^{\prime}(G-L),
$$

where $\theta$ is the net advantage to attending NEU, $L$ is loan payments, $G$ is earnings on a good job, B is earnings on a bad job, and $\mathrm{p}$ is the probability that the individual gets a good job after college.

Assuming that the marginal utility of income is decreasing, equation (5) is negative, and the marginal disutility of loans increases as $p$ decreases. Thus, those with a lower value of $p$ (and hence with lower expected future earnings) will be more averse to financing their education through debt. That minorities may expect lower future earnings than non-minorities is consistent with much of the empirical literature (e.g., Neal and Johnson [1996]). A difference in expected future earnings therefore provides a plausible explanation for why the effect of NEU's change in financial aid policy was larger for minority students.

\section{Conclusion}

We examine a program instituted at a Northeastern university to replace loans with grant aid for low-income students. We find the program increased the likelihood of matriculation by low-income students by about 3 percentage points, although the effect is not statistically significant. The effect among low-income minority students was between 8 and 10 percentage points and statistically significant at the 10 percent level. That the program appears to have had a larger effect on minorities than non-minorities is consistent with a lower expectation of post-college earnings among minorities. While it 
is perilous to generalize on the basis of the experience of a single institution, an important lesson emerges from our analysis: as in so many other areas of economics, expectations can play an important role in the efficacy of programs and should be incorporated into their initial design and analysis. 


\section{References}

Consortium on Financing Higher Education (COFHE). 1998. "Tuition, Student Budgets, and Self-Help at the Consortium Institutions for Academic Year 1998-99." (COFHE Yellow Book), (June).

Digest of Education Statistics. 2000. (Washington, D.C.: Department of Health, Education, and Welfare, Education Division, National Center for Education Statistics).

Dynarski, Susan. 1999. "Does Aid Matter? Measuring the Effect of Student Aid on College Attendance and Completion," NBER Working Paper \#7422.

Dynarski, Susan. 2000. "Hope for Whom? Financial Aid for the Middle Class and Its Impact on College Attendance." National Tax Journal 53(3), Sept 2000 part 2: 629-661.

Ehrenberg, Ronald G. and Daniel R. Sherman. 1984. “Optimal Financial Aid Policies for a Selective University." Journal of Human Resources 19(2): 202-30.

Feldstein, Martin. 1992. “College Scholarship Rules and Private Saving," NBER Working Paper \#4032.

Hoenack, Stephen. 1971. "The Efficient Allocation of Subsidies to Higher Education." American Economic Review, 61 (June): 302-311.

Jackson, Gregory A. 1990. "Financial Aid, College Entry, and Affirmative Action." American Journal of Education, August 1990, 523-550.

Kane, Thomas. 1994. "College Entry by Blacks since 1970: The Role of College Costs, Family Background, and the Returns to Education." The Journal of Political Economy, 102(5): 878-911.

Kane, Thomas. 1999. The Price of Admission: Rethinking How Americans Pay for College. Washington, DC: The Brookings Institution.

Manski, Charles F. and David A. Wise. 1983. College Choice in America. Cambridge: Harvard University Press.

McPherson, Michael S. and Morton Owen Schapiro. 1991a. Keeping College Affordable: Government and Educational Opportunity. Washington, DC: The Brookings Institution.

McPherson, Michael S. and Morton Owen Schapiro. 1991b. "Does Student Aid Affect College Enrollment? New Evidence on a Persistent Controversy." American Economic Review 81(1): 309-318. 
Moore, Robert L., A. H. Studenmund, and Thomas Slobko. 1991. "The Effect of the Financial Aid Package on the Choice of a Selective College." Economics of Education Review, 10(4), 311-321.

Neal, Derek A. and William A. Johnson. 1996. "The Role of Premarket Factors in Black-White Wage Differences." Journal of Political Economy 104: 869-895.

Rouse, Cecilia Elena. 1994. "What to Do After High School: The Two-Year versus Four-year College Enrollment Decision." Choices and Consequences: Contemporary Policy Issues in Education (Ronald G. Ehrenberg, editor) (Ithaca, NY: ILR Press).

Savoca, Elizabeth. 1991. "The Effect of Changes in the Composition of Financial Aid on College Enrollments" Eastern Economic Journal 17(1): 109-121.

Schwartz, J. Brad. 1985. "Student Financial Aid and the College Enrollment Decision: the Effects of Public and Private Grants and Interest Subsidies." Economics of Education Review. 4(2), 129-144.

U.S. Department of Education, "SFA [Student Financial Aid] Handbook," 1997-1998, 1998-1999, and 1999-2000 versions. At http://ifap.ed.gov/csb_html/fsfabknew.htm

van der Klaauw, Wilbert. 1996. "A Regression-Discontinuity Evaluation of the Effect of Financial Aid Offers on College Enrollment," New York University mimeo, forthcoming in International Economic Review, 2002. 
Table 1:

Means of Student Characteristics

Regular Admission U.S. Citizens in the Graduating Classes of 1992-2004

\begin{tabular}{|c|c|c|c|c|c|c|}
\hline & \multicolumn{3}{|c|}{ Admitted } & \multicolumn{3}{|c|}{ Enrolled } \\
\hline & All & $\begin{array}{l}\text { Not low- } \\
\text { income }\end{array}$ & $\begin{array}{c}\text { Low- } \\
\text { income }\end{array}$ & All & $\begin{array}{l}\text { Not low- } \\
\text { income }\end{array}$ & $\begin{array}{l}\text { Low- } \\
\text { income }\end{array}$ \\
\hline Low-income & 0.101 & 0.000 & 1.000 & 0.109 & 0.000 & 1.000 \\
\hline Financial Aid Recipient & 0.487 & 0.432 & 0.983 & 0.515 & 0.457 & 0.989 \\
\hline Financial Aid Applicant & 0.618 & 0.576 & 1.000 & 0.642 & 0.598 & 1.000 \\
\hline Female & 0.470 & 0.470 & 0.473 & 0.448 & 0.448 & 0.454 \\
\hline \multicolumn{7}{|l|}{ Census Division: } \\
\hline New England & 0.054 & 0.055 & 0.042 & 0.050 & 0.051 & 0.038 \\
\hline Middle Atlantic & 0.320 & 0.325 & 0.278 & 0.358 & 0.362 & 0.328 \\
\hline East North Central & 0.101 & 0.104 & 0.067 & 0.095 & 0.099 & 0.059 \\
\hline West North Central & 0.034 & 0.034 & 0.030 & 0.030 & 0.029 & 0.032 \\
\hline South Atlantic & 0.113 & 0.112 & 0.117 & 0.113 & 0.114 & 0.109 \\
\hline East South Central & 0.062 & 0.062 & 0.065 & 0.066 & 0.066 & 0.066 \\
\hline West South Central & 0.068 & 0.064 & 0.111 & 0.070 & 0.065 & 0.109 \\
\hline Mountain & 0.034 & 0.032 & 0.048 & 0.030 & 0.028 & 0.047 \\
\hline Pacific & 0.172 & 0.171 & 0.175 & 0.140 & 0.140 & 0.141 \\
\hline \multicolumn{7}{|l|}{ Academic Rating: } \\
\hline A & 0.266 & 0.279 & 0.143 & 0.176 & 0.184 & 0.109 \\
\hline $\mathrm{B}$ & 0.355 & 0.366 & 0.256 & 0.354 & 0.369 & 0.235 \\
\hline C & 0.222 & 0.210 & 0.337 & 0.254 & 0.246 & 0.323 \\
\hline $\mathrm{D}$ & 0.126 & 0.114 & 0.233 & 0.171 & 0.157 & 0.284 \\
\hline$E$ & 0.022 & 0.021 & 0.030 & 0.038 & 0.037 & 0.047 \\
\hline \multicolumn{7}{|l|}{ Non Academic Rating: } \\
\hline A & 0.022 & 0.023 & 0.012 & 0.023 & 0.024 & 0.013 \\
\hline $\mathrm{B}$ & 0.215 & 0.222 & 0.157 & 0.246 & 0.254 & 0.186 \\
\hline $\mathrm{C}$ & 0.433 & 0.439 & 0.376 & 0.436 & 0.441 & 0.391 \\
\hline D & 0.301 & 0.288 & 0.413 & 0.271 & 0.260 & 0.366 \\
\hline E & 0.020 & 0.017 & 0.041 & 0.017 & 0.014 & 0.042 \\
\hline Admissions Ratings Missing & 0.009 & 0.010 & 0.001 & 0.007 & 0.007 & 0.003 \\
\hline Athlete & 0.153 & 0.157 & 0.117 & 0.228 & 0.236 & 0.169 \\
\hline Alumni child & 0.065 & 0.071 & 0.017 & 0.091 & 0.100 & 0.015 \\
\hline African-American & 0.146 & 0.129 & 0.297 & 0.118 & 0.100 & 0.263 \\
\hline Hispanic & 0.102 & 0.085 & 0.257 & 0.095 & 0.078 & 0.230 \\
\hline Native American & 0.010 & 0.008 & 0.021 & 0.011 & 0.008 & 0.029 \\
\hline Asian & 0.152 & 0.158 & 0.101 & 0.121 & 0.125 & 0.087 \\
\hline Minority & 0.257 & 0.221 & 0.576 & 0.223 & 0.186 & 0.522 \\
\hline Number of Observations & 13701 & 12322 & 1379 & 6558 & 5842 & 716 \\
\hline
\end{tabular}

Note: Minority includes African-American, Hispanic, and Native American. 
Table 2:

Time Series of Student Characteristics

Regular Admission U.S. Citizens in the Graduating Classes of 1992-2004

\begin{tabular}{|c|c|c|c|c|c|c|c|c|c|c|c|c|}
\hline \multirow[b]{2}{*}{ Class } & \multirow[b]{2}{*}{$\begin{array}{l}\text { Low- } \\
\text { income }\end{array}$} & \multirow[b]{2}{*}{$\begin{array}{l}\text { Financial } \\
\text { Aid } \\
\text { Recipient } \\
\end{array}$} & \multirow[b]{2}{*}{$\begin{array}{l}\text { Financial } \\
\text { Aid } \\
\text { applicant }\end{array}$} & \multirow[b]{2}{*}{ Female } & \multirow[b]{2}{*}{ Minority } & \multicolumn{2}{|c|}{ Proportion $A$ or $B^{1}$} & \multirow[b]{2}{*}{ Athlete } & \multirow[b]{2}{*}{$\begin{array}{l}\text { Alumni } \\
\text { Child }\end{array}$} & \multirow[b]{2}{*}{$\begin{array}{c}\text { Median } \\
\text { Income of Aid } \\
\text { Applicants }\end{array}$} & \multirow[b]{2}{*}{$\begin{array}{c}\text { Average } \\
\text { Financial Aid } \\
\text { Award }^{2}\end{array}$} & \multirow[b]{2}{*}{$\begin{array}{c}\text { Cost of } \\
\text { Attendance }\end{array}$} \\
\hline & & & & & & $\begin{array}{l}\text { Acad. } \\
\text { Rating }\end{array}$ & $\begin{array}{c}\text { Nonacad. } \\
\text { Rating }\end{array}$ & & & & & \\
\hline \multicolumn{13}{|c|}{ Admitted students } \\
\hline 1992 & 0.096 & 0.449 & 0.571 & 0.395 & 0.200 & 0.552 & 0.508 & 0.173 & 0.086 & $\$ 77,111$ & $\$ 11,037$ & $\$ 27,729$ \\
\hline 1993 & 0.117 & 0.480 & 0.603 & 0.439 & 0.229 & 0.518 & 0.198 & 0.188 & 0.078 & $\$ 76,330$ & $\$ 12,262$ & $\$ 28,241$ \\
\hline 1994 & 0.109 & 0.470 & 0.595 & 0.454 & 0.233 & 0.592 & 0.174 & 0.174 & 0.060 & $\$ 79,229$ & $\$ 12,421$ & $\$ 28,553$ \\
\hline 1995 & 0.088 & 0.473 & 0.612 & 0.453 & 0.247 & 0.568 & 0.176 & 0.181 & 0.076 & $\$ 79,049$ & $\$ 12,575$ & $\$ 29,198$ \\
\hline 1996 & 0.100 & 0.492 & 0.598 & 0.486 & 0.246 & 0.527 & 0.178 & 0.182 & 0.055 & $\$ 78,404$ & $\$ 14,397$ & $\$ 30,102$ \\
\hline 1997 & 0.098 & 0.486 & 0.615 & 0.462 & 0.280 & 0.612 & 0.201 & 0.157 & 0.050 & $\$ 85,151$ & $\$ 13,768$ & $\$ 30,916$ \\
\hline 1998 & 0.107 & 0.505 & 0.609 & 0.494 & 0.283 & 0.593 & 0.210 & 0.161 & 0.058 & $\$ 84,543$ & $\$ 16,920$ & $\$ 31,544$ \\
\hline 1999 & 0.094 & 0.522 & 0.643 & 0.493 & 0.282 & 0.616 & 0.195 & 0.163 & 0.049 & $\$ 79,297$ & $\$ 18,651$ & $\$ 32,139$ \\
\hline 2000 & 0.107 & 0.506 & 0.641 & 0.483 & 0.259 & 0.694 & 0.206 & 0.124 & 0.066 & $\$ 82,554$ & $\$ 16,623$ & $\$ 31,856$ \\
\hline 2001 & 0.083 & 0.479 & 0.654 & 0.480 & 0.253 & 0.690 & 0.247 & 0.123 & 0.060 & $\$ 91,620$ & $\$ 16,234$ & $\$ 33,081$ \\
\hline 2002 & 0.096 & 0.534 & 0.656 & 0.510 & 0.284 & 0.722 & 0.233 & 0.111 & 0.062 & $\$ 88,947$ & $\$ 19,479$ & $\$ 33,780$ \\
\hline 2003 & 0.110 & 0.479 & 0.656 & 0.498 & 0.277 & 0.774 & 0.243 & 0.110 & 0.069 & $\$ 94,531$ & $\$ 16,750$ & $\$ 34,180$ \\
\hline 2004 & 0.098 & 0.478 & 0.627 & 0.519 & 0.314 & 0.735 & 0.277 & 0.094 & 0.071 & $\$ 92,018$ & $\$ 18,372$ & $\$ 34,171$ \\
\hline \multicolumn{13}{|c|}{ Enrolled students } \\
\hline 1992 & 0.102 & 0.454 & 0.570 & 0.395 & 0.162 & 0.465 & 0.511 & 0.249 & 0.117 & $\$ 73,270$ & $\$ 13,701$ & $\$ 27,729$ \\
\hline 1993 & 0.122 & 0.481 & 0.593 & 0.431 & 0.185 & 0.386 & 0.202 & 0.273 & 0.132 & $\$ 73,420$ & $\$ 13,970$ & $\$ 28,241$ \\
\hline 1994 & 0.134 & 0.520 & 0.644 & 0.420 & 0.225 & 0.483 & 0.195 & 0.259 & 0.086 & $\$ 77,548$ & $\$ 14,676$ & $\$ 28,553$ \\
\hline 1995 & 0.070 & 0.493 & 0.628 & 0.415 & 0.189 & 0.439 & 0.215 & 0.280 & 0.122 & $\$ 80,959$ & $\$ 14,232$ & $\$ 29,198$ \\
\hline 1996 & 0.105 & 0.547 & 0.649 & 0.440 & 0.200 & 0.425 & 0.211 & 0.275 & 0.092 & $\$ 72,731$ & $\$ 16,857$ & $\$ 30,102$ \\
\hline 1997 & 0.113 & 0.547 & 0.670 & 0.414 & 0.234 & 0.496 & 0.254 & 0.262 & 0.082 & $\$ 82,374$ & $\$ 15,980$ & $\$ 30,916$ \\
\hline 1998 & 0.113 & 0.551 & 0.632 & 0.472 & 0.247 & 0.490 & 0.253 & 0.251 & 0.069 & $\$ 80,587$ & $\$ 18,355$ & $\$ 31,544$ \\
\hline 1999 & 0.101 & 0.575 & 0.695 & 0.478 & 0.268 & 0.518 & 0.223 & 0.243 & 0.066 & $\$ 78,200$ & $\$ 19,210$ & $\$ 32,139$ \\
\hline 2000 & 0.127 & 0.532 & 0.667 & 0.478 & 0.236 & 0.604 & 0.230 & 0.187 & 0.076 & $\$ 79,516$ & $\$ 17,779$ & $\$ 31,856$ \\
\hline 2001 & 0.079 & 0.484 & 0.662 & 0.445 & 0.211 & 0.630 & 0.284 & 0.184 & 0.086 & $\$ 89,644$ & $\$ 16,569$ & $\$ 33,081$ \\
\hline 2002 & 0.095 & 0.556 & 0.673 & 0.496 & 0.250 & 0.649 & 0.264 & 0.163 & 0.071 & $\$ 88,623$ & $\$ 20,136$ & $\$ 33,780$ \\
\hline 2003 & 0.144 & 0.499 & 0.672 & 0.457 & 0.247 & 0.698 & 0.300 & 0.171 & 0.079 & $\$ 86,343$ & $\$ 19,286$ & $\$ 34,180$ \\
\hline 2004 & 0.108 & 0.476 & 0.616 & 0.517 & 0.271 & 0.679 & 0.318 & 0.144 & 0.093 & $\$ 89,611$ & $\$ 19,587$ & $\$ 34,171$ \\
\hline
\end{tabular}

Notes: Only includes non-early admission U.S. citizens. Minority students include those who self-report as African-American, Hispanic, or Native American. All dollar amounts are in 1999 dollars. The cost of attendance is the university's published total of tuition, fees, room and board, and additional expenses. Whether or not a student is categorized as "low-income" is defined retroactively according to the post-2002 definition (see text). 1 "A" is the highest admissions rating; "B" is the second highest (see text). Non-academic rating is 1992 is coded differently and is not comparable.

2 Among financial aid recipients. 
Table 3:

Yield Rates at NEU for the Graduating Classes of 1992-2004

\begin{tabular}{|c|c|c|c|c|c|c|}
\hline \multirow[b]{3}{*}{ Graduating Class } & \multirow[b]{3}{*}{ All admits } & \multicolumn{5}{|c|}{ Regular admission US citizens } \\
\hline & & & \multicolumn{2}{|c|}{ All } & \multicolumn{2}{|c|}{ Minority } \\
\hline & & All & $\begin{array}{l}\text { Not low- } \\
\text { income }\end{array}$ & $\begin{array}{c}\text { Low- } \\
\text { income }\end{array}$ & $\begin{array}{l}\text { Not low- } \\
\text { income }\end{array}$ & $\begin{array}{c}\text { Low- } \\
\text { income }\end{array}$ \\
\hline 1992 & $54.59 \%$ & $47.30 \%$ & $47.01 \%$ & $50.00 \%$ & $34.29 \%$ & $53.57 \%$ \\
\hline 1993 & $54.81 \%$ & $46.75 \%$ & $46.50 \%$ & $48.65 \%$ & $37.44 \%$ & $38.46 \%$ \\
\hline 1994 & $55.93 \%$ & $46.53 \%$ & $45.26 \%$ & $56.83 \%$ & $40.19 \%$ & $58.02 \%$ \\
\hline 1995 & $55.93 \%$ & $42.91 \%$ & $43.76 \%$ & $34.04 \%$ & $35.61 \%$ & $23.33 \%$ \\
\hline 1996 & $56.34 \%$ & $43.02 \%$ & $42.81 \%$ & $44.86 \%$ & $33.50 \%$ & $39.68 \%$ \\
\hline 1997 & $57.82 \%$ & $43.88 \%$ & $43.17 \%$ & $50.46 \%$ & $35.48 \%$ & $41.27 \%$ \\
\hline 1998 & $58.98 \%$ & $45.66 \%$ & $45.34 \%$ & $48.28 \%$ & $39.48 \%$ & $41.10 \%$ \\
\hline 1999 & $62.96 \%$ & $48.55 \%$ & $48.18 \%$ & $52.13 \%$ & $46.05 \%$ & $46.30 \%$ \\
\hline 2000 & $68.80 \%$ & $51.26 \%$ & $50.12 \%$ & $60.78 \%$ & $44.81 \%$ & $52.38 \%$ \\
\hline 2001 & $68.13 \%$ & $50.32 \%$ & $50.52 \%$ & $48.10 \%$ & $41.03 \%$ & $45.65 \%$ \\
\hline 2002 & $71.86 \%$ & $54.69 \%$ & $54.76 \%$ & $54.02 \%$ & $46.41 \%$ & $55.10 \%$ \\
\hline 2003 & $70.95 \%$ & $52.89 \%$ & $50.85 \%$ & $69.46 \%$ & $40.54 \%$ & $70.37 \%$ \\
\hline 2004 & $72.52 \%$ & $53.12 \%$ & $52.53 \%$ & $58.54 \%$ & $44.23 \%$ & $51.85 \%$ \\
\hline Average & $61.50 \%$ & $47.87 \%$ & $47.41 \%$ & $51.92 \%$ & $39.87 \%$ & $47.10 \%$ \\
\hline Number of Observations & 24805 & 13701 & 12322 & 1379 & 2729 & 794 \\
\hline
\end{tabular}

Minority students include those who self-report as African-American, Hispanic, or Native American. 
Table 4:

Probit Analysis of Enrollment Decision at NEU

\begin{tabular}{|c|c|c|c|c|c|}
\hline & \multicolumn{4}{|c|}{ Regular Admission U.S. Citizens } & \multirow[b]{2}{*}{$\begin{array}{l}\text { Reintroduce } \\
\text { Early } \\
\text { Applicants } \\
\text { (5) }\end{array}$} \\
\hline & $\begin{array}{l}\text { No Controls } \\
\text { (1) }\end{array}$ & $\begin{array}{c}\text { Add Student } \\
\text { Characteristics } \\
\text { (2) }\end{array}$ & $\begin{array}{l}\text { Add Middle- } \\
\text { Income } \\
\text { Controls } \\
\text { (3) }\end{array}$ & $\begin{array}{l}\text { Allow for Class } \\
\text { Effects } \\
(4)\end{array}$ & \\
\hline Low-income & $\begin{array}{c}0.036 \\
(0.016)\end{array}$ & $\begin{array}{l}-0.038 \\
(0.019)\end{array}$ & $\begin{array}{l}-0.034 \\
(0.020)\end{array}$ & $\begin{array}{l}-0.052 \\
(0.057)\end{array}$ & $\begin{array}{c}0.004 \\
(0.040)\end{array}$ \\
\hline Program & $\begin{array}{c}0.066 \\
(0.011)\end{array}$ & $\begin{array}{c}0.168 \\
(0.013)\end{array}$ & $\begin{array}{c}0.166 \\
(0.013)\end{array}$ & & \\
\hline Program * Low-income & $\begin{array}{c}0.047 \\
(0.036)\end{array}$ & $\begin{array}{c}0.020 \\
(0.038)\end{array}$ & $\begin{array}{c}0.023 \\
(0.038)\end{array}$ & & \\
\hline Net program effect & & & & $\begin{array}{c}0.023 \\
(0.039)\end{array}$ & $\begin{array}{c}0.010 \\
(0.028)\end{array}$ \\
\hline $\begin{array}{l}\text { Financial Aid Award } / 10^{3} \\
(\$ 1999)\end{array}$ & & $\begin{array}{c}0.006 \\
(0.001)\end{array}$ & $\begin{array}{c}0.006 \\
(0.001)\end{array}$ & $\begin{array}{c}0.005 \\
(0.001)\end{array}$ & $\begin{array}{c}0.004 \\
(0.000)\end{array}$ \\
\hline Female & & $\begin{array}{l}-0.026 \\
(0.009)\end{array}$ & $\begin{array}{l}-0.026 \\
(0.009)\end{array}$ & $\begin{array}{l}-0.029 \\
(0.009)\end{array}$ & $\begin{array}{l}-0.024 \\
(0.007)\end{array}$ \\
\hline Alumni Child & & $\begin{array}{c}0.155 \\
(0.019)\end{array}$ & $\begin{array}{c}0.155 \\
(0.019)\end{array}$ & $\begin{array}{c}0.150 \\
(0.019)\end{array}$ & $\begin{array}{c}0.146 \\
(0.014)\end{array}$ \\
\hline $\begin{array}{l}\text { Academic Rating: } \\
\text { A }\end{array}$ & & $\begin{array}{l}-0.644 \\
(0.040)\end{array}$ & $\begin{array}{l}-0.648 \\
(0.040)\end{array}$ & $\begin{array}{l}-0.698 \\
(0.041)\end{array}$ & $\begin{array}{l}-0.600 \\
(0.032)\end{array}$ \\
\hline $\mathrm{B}$ & & $\begin{array}{l}-0.423 \\
(0.039)\end{array}$ & $\begin{array}{l}-0.423 \\
(0.039)\end{array}$ & $\begin{array}{l}-0.454 \\
(0.040)\end{array}$ & $\begin{array}{l}-0.416 \\
(0.031)\end{array}$ \\
\hline $\mathrm{C}$ & & $\begin{array}{l}-0.265 \\
(0.038)\end{array}$ & $\begin{array}{l}-0.265 \\
(0.038)\end{array}$ & $\begin{array}{l}-0.289 \\
(0.039)\end{array}$ & $\begin{array}{l}-0.266 \\
(0.030)\end{array}$ \\
\hline $\mathrm{D}$ & & $\begin{array}{l}-0.152 \\
(0.039)\end{array}$ & $\begin{array}{l}-0.153 \\
(0.039)\end{array}$ & $\begin{array}{l}-0.166 \\
(0.039)\end{array}$ & $\begin{array}{l}-0.145 \\
(0.031)\end{array}$ \\
\hline $\begin{array}{l}\text { Non-academic Rating: } \\
\text { A }\end{array}$ & & $\begin{array}{l}-0.206 \\
(0.045)\end{array}$ & $\begin{array}{l}-0.206 \\
(0.045)\end{array}$ & $\begin{array}{l}-0.218 \\
(0.046)\end{array}$ & $\begin{array}{l}-0.225 \\
(0.032)\end{array}$ \\
\hline B & & $\begin{array}{l}-0.057 \\
-(0.006)\end{array}$ & $\begin{array}{l}-0.057 \\
(0.034)\end{array}$ & $\begin{array}{l}-0.060 \\
(0.035)\end{array}$ & $\begin{array}{l}-0.072 \\
(0.024)\end{array}$ \\
\hline $\mathrm{C}$ & & $\begin{array}{l}-0.006 \\
(0.032)\end{array}$ & $\begin{array}{l}-0.006 \\
(0.033)\end{array}$ & $\begin{array}{l}-0.007 \\
(0.033)\end{array}$ & $\begin{array}{l}-0.022 \\
(0.023)\end{array}$ \\
\hline $\mathrm{D}$ & & $\begin{array}{c}0.006 \\
(0.033)\end{array}$ & $\begin{array}{c}0.007 \\
(0.033)\end{array}$ & $\begin{array}{c}0.008 \\
(0.033)\end{array}$ & $\begin{array}{l}-0.010 \\
(0.023)\end{array}$ \\
\hline Admissions Ratings Missing & & $\begin{array}{l}-0.565 \\
(0.068)\end{array}$ & $\begin{array}{l}-0.566 \\
(0.068)\end{array}$ & $\begin{array}{l}-0.563 \\
(0.069)\end{array}$ & $\begin{array}{l}-0.581 \\
(0.046)\end{array}$ \\
\hline Recruited Athlete & & 0.084 & 0.084 & 0.078 & 0.038 \\
\hline
\end{tabular}




\begin{tabular}{|c|c|c|c|c|}
\hline & $(0.017)$ & $(0.017)$ & $(0.017)$ & $(0.013)$ \\
\hline African-American & $\begin{array}{l}-0.370 \\
(0.017)\end{array}$ & $\begin{array}{l}-0.370 \\
(0.017)\end{array}$ & $\begin{array}{l}-0.385 \\
(0.017)\end{array}$ & $\begin{array}{l}-0.339 \\
(0.013)\end{array}$ \\
\hline Latino & $\begin{array}{l}-0.263 \\
(0.028)\end{array}$ & $\begin{array}{l}-0.263 \\
(0.028)\end{array}$ & $\begin{array}{c}-0.276 \\
-(0.276)\end{array}$ & $\begin{array}{l}-0.226 \\
(0.023)\end{array}$ \\
\hline Mexican & $\begin{array}{l}-0.300 \\
(0.023)\end{array}$ & $\begin{array}{l}-0.300 \\
(0.023)\end{array}$ & $\begin{array}{l}-0.314 \\
(0.024)\end{array}$ & $\begin{array}{l}-0.270 \\
(0.019)\end{array}$ \\
\hline Other Hispanic & $\begin{array}{l}-0.097 \\
(0.043)\end{array}$ & $\begin{array}{l}-0.098 \\
(0.043)\end{array}$ & $\begin{array}{l}-0.099 \\
(0.043)\end{array}$ & $\begin{array}{l}-0.107 \\
(0.029)\end{array}$ \\
\hline Native American & $\begin{array}{l}-0.145 \\
(0.047)\end{array}$ & $\begin{array}{l}-0.145 \\
(0.047)\end{array}$ & $\begin{array}{l}-0.161 \\
(0.047)\end{array}$ & $\begin{array}{l}-0.174 \\
(0.040)\end{array}$ \\
\hline Asian & $\begin{array}{l}-0.047 \\
(0.013)\end{array}$ & $\begin{array}{l}-0.047 \\
(0.013)\end{array}$ & $\begin{array}{l}-0.053 \\
(0.014)\end{array}$ & $\begin{array}{l}-0.056 \\
(0.010)\end{array}$ \\
\hline Middle Income & & $\begin{array}{l}(0.009) \\
(0.021)\end{array}$ & & \\
\hline Middle Income * Program & & $\begin{array}{l}(0.023) \\
(0.044)\end{array}$ & & \\
\hline $\begin{array}{l}\text { Graduating Class } \\
1992\end{array}$ & & & $\begin{array}{l}-0.087 \\
(0.024)\end{array}$ & $\begin{array}{l}-0.074 \\
(0.017)\end{array}$ \\
\hline 1993 & & & $\begin{array}{l}-0.084 \\
(0.024)\end{array}$ & $\begin{array}{l}-0.076 \\
(0.017)\end{array}$ \\
\hline 1994 & & & $\begin{array}{l}-0.088 \\
(0.024)\end{array}$ & $\begin{array}{l}-0.058 \\
(0.017)\end{array}$ \\
\hline 1995 & & & $\begin{array}{l}-0.102 \\
(0.025)\end{array}$ & $\begin{array}{l}-0.073 \\
(0.017)\end{array}$ \\
\hline 1996 & & & $\begin{array}{l}-0.092 \\
(0.025)\end{array}$ & $\begin{array}{l}-0.063 \\
(0.017)\end{array}$ \\
\hline 1997 & & & $\begin{array}{l}-0.074 \\
(0.024)\end{array}$ & $\begin{array}{l}-0.043 \\
(0.017)\end{array}$ \\
\hline 1998 & & & $\begin{array}{l}-0.054 \\
(0.024)\end{array}$ & $\begin{array}{l}-0.038 \\
(0.017)\end{array}$ \\
\hline 2000 & & & $\begin{array}{c}0.056 \\
(0.025)\end{array}$ & -- \\
\hline 2001 & & & $\begin{array}{c}0.053 \\
(0.025)\end{array}$ & $\begin{array}{l}-0.010 \\
(0.020)\end{array}$ \\
\hline 2002 & & & $\begin{array}{c}0.129 \\
(0.025)\end{array}$ & $\begin{array}{c}0.058 \\
(0.020)\end{array}$ \\
\hline 2003 & & & $\begin{array}{c}0.106 \\
(0.026)\end{array}$ & $\begin{array}{l}0.035 \\
(0.020)\end{array}$ \\
\hline 2004 & & & $\begin{array}{c}0.138 \\
(0.026)\end{array}$ & $\begin{array}{c}0.071 \\
(0.020)\end{array}$ \\
\hline $\begin{array}{l}\text { Low-income * Graduating Class } \\
1992\end{array}$ & & & 0.051 & -0.020 \\
\hline
\end{tabular}




\begin{tabular}{|c|c|c|c|c|c|}
\hline & & & & $(0.074)$ & $(0.053)$ \\
\hline 1993 & & & & $\begin{array}{c}0.010 \\
(0.073)\end{array}$ & $\begin{array}{l}-0.054 \\
(0.052)\end{array}$ \\
\hline 1994 & & & & $\begin{array}{c}0.152 \\
(0.074)\end{array}$ & $\begin{array}{c}0.089 \\
(0.053)\end{array}$ \\
\hline 1995 & & & & $\begin{array}{l}-0.106 \\
(0.082)\end{array}$ & $\begin{array}{l}-0.132 \\
(0.055)\end{array}$ \\
\hline 1996 & & & & $\begin{array}{c}0.012 \\
(0.078)\end{array}$ & $\begin{array}{l}-0.055 \\
(0.054)\end{array}$ \\
\hline 1997 & & & & $\begin{array}{c}0.036 \\
(0.077)\end{array}$ & $\begin{array}{l}-0.038 \\
(0.054)\end{array}$ \\
\hline 1998 & & & & $\begin{array}{c}0.004 \\
(0.076)\end{array}$ & $\begin{array}{c}0.014 \\
(0.055)\end{array}$ \\
\hline 2000 & & & & $\begin{array}{c}0.040 \\
(0.079)\end{array}$ & $\begin{array}{l}-0.039 \\
(0.058)\end{array}$ \\
\hline 2001 & & & & $\begin{array}{l}-0.065 \\
(0.083)\end{array}$ & $\begin{array}{l}-0.102 \\
(0.060)\end{array}$ \\
\hline 2002 & & & & $\begin{array}{l}-0.066 \\
(0.081)\end{array}$ & $\begin{array}{l}-0.089 \\
(0.059)\end{array}$ \\
\hline 2003 & & & & $\begin{array}{c}0.163 \\
(0.081)\end{array}$ & $\begin{array}{c}0.050 \\
(0.058)\end{array}$ \\
\hline 2004 & & & & $\begin{array}{c}0.019 \\
(0.084)\end{array}$ & $\begin{array}{l}-0.042 \\
(0.059)\end{array}$ \\
\hline plied early action/decision & & & & & $\begin{array}{c}0.425 \\
(0.008)\end{array}$ \\
\hline rly decision year & & & & & $\begin{array}{c}0.135 \\
(0.019)\end{array}$ \\
\hline nsus Division dummies & No & Yes & Yes & Yes & Yes \\
\hline g Likelihood & -9457.319 & -8444.490 & -8444.121 & -8376.591 & -13023.924 \\
\hline Imber of Observations & 13701 & 13701 & 13701 & 13701 & 24805 \\
\hline se Probability & 0.479 & 0.479 & 0.479 & 0.479 & 0.615 \\
\hline
\end{tabular}

Notes: Standard errors are in parentheses. Coefficients reported are marginal effects.

The net program effect in columns (4) and (5) is calculated as the average of the Class * Low-income interactions after the policy change (2002-2004) minus the average of the interactions before the policy change. The base probability is the predicted probability of enrollment evaluated at the mean student characteristics. Class of 2000 effect is omitted in column (5) because of colinearity with program and early decision year 
Table 5:

Alternative Samples

\begin{tabular}{|c|c|c|c|c|}
\hline & \multicolumn{4}{|c|}{ Sample Excludes the Specified Graduation Classes } \\
\hline & $\begin{array}{c}2001 \\
(1) \\
\end{array}$ & $\begin{array}{l}2000 \text { and } 2001 \\
\text { (2) }\end{array}$ & $\begin{array}{c}\text { All Classes Before } \\
1997 \\
(3) \\
\end{array}$ & $\begin{array}{c}\text { Pre-1997, 2000, } \\
2001 \\
(4) \\
\end{array}$ \\
\hline Low-income & $\begin{array}{l}-0.034 \\
(0.019)\end{array}$ & $\begin{array}{l}-0.036 \\
(0.020)\end{array}$ & $\begin{array}{l}-0.035 \\
(0.027)\end{array}$ & $\begin{array}{l}-0.037 \\
(0.034)\end{array}$ \\
\hline Program & $\begin{array}{c}0.180 \\
(0.013)\end{array}$ & $\begin{array}{c}0.194 \\
(0.013)\end{array}$ & $\begin{array}{c}0.129 \\
(0.014)\end{array}$ & $\begin{array}{c}0.167 \\
(0.016)\end{array}$ \\
\hline Program * Low-income & $\begin{array}{c}0.011 \\
(0.038)\end{array}$ & $\begin{array}{c}0.012 \\
(0.039)\end{array}$ & $\begin{array}{c}0.034 \\
(0.042)\end{array}$ & $\begin{array}{c}0.024 \\
(0.046)\end{array}$ \\
\hline $\begin{array}{l}\text { Financial Aid Award } / 10^{3} \\
(\$ 1999)\end{array}$ & $\begin{array}{l}0.006 \\
(0.001)\end{array}$ & $\begin{array}{c}0.006 \\
(0.001)\end{array}$ & $\begin{array}{c}0.005 \\
(0.001)\end{array}$ & $\begin{array}{l}0.006 \\
(0.001)\end{array}$ \\
\hline Female & $\begin{array}{l}-0.025 \\
(0.009)\end{array}$ & $\begin{array}{l}-0.029 \\
(0.010)\end{array}$ & $\begin{array}{l}-0.026 \\
(0.012)\end{array}$ & $\begin{array}{l}-0.027 \\
(0.014)\end{array}$ \\
\hline Alumni Child & $\begin{array}{c}0.149 \\
(0.020)\end{array}$ & $\begin{array}{c}0.158 \\
(0.021)\end{array}$ & $\begin{array}{c}0.112 \\
(0.026)\end{array}$ & $\begin{array}{c}0.110 \\
(0.030)\end{array}$ \\
\hline $\begin{array}{l}\text { Academic Rating: } \\
\text { A }\end{array}$ & $\begin{array}{l}-0.657 \\
(0.041)\end{array}$ & $\begin{array}{l}-0.661 \\
(0.042)\end{array}$ & $\begin{array}{l}-0.730 \\
(0.075)\end{array}$ & $\begin{array}{l}-0.705 \\
(0.080)\end{array}$ \\
\hline $\mathrm{B}$ & $\begin{array}{l}-0.427 \\
(0.040)\end{array}$ & $\begin{array}{l}-0.426 \\
(0.040)\end{array}$ & $\begin{array}{l}-0.492 \\
(0.074)\end{array}$ & $\begin{array}{l}-0.465 \\
(0.078)\end{array}$ \\
\hline $\mathrm{C}$ & $\begin{array}{l}-0.263 \\
(0.039)\end{array}$ & $\begin{array}{l}-0.262 \\
(0.039)\end{array}$ & $\begin{array}{l}-0.334 \\
(0.073)\end{array}$ & $\begin{array}{l}-0.303 \\
(0.078)\end{array}$ \\
\hline $\mathrm{D}$ & $\begin{array}{l}-0.148 \\
(0.039)\end{array}$ & $\begin{array}{l}-0.145 \\
(0.040)\end{array}$ & $\begin{array}{l}-0.229 \\
(0.074)\end{array}$ & $\begin{array}{l}-0.193 \\
(0.078)\end{array}$ \\
\hline $\begin{array}{l}\text { Non-academic Rating: } \\
\text { A }\end{array}$ & $\begin{array}{l}-0.226 \\
(0.047)\end{array}$ & $\begin{array}{l}-0.232 \\
(0.049)\end{array}$ & $\begin{array}{l}-0.204 \\
(0.060)\end{array}$ & $\begin{array}{l}-0.244 \\
(0.070)\end{array}$ \\
\hline $\mathrm{B}$ & $\begin{array}{l}-0.066 \\
(0.035)\end{array}$ & $\begin{array}{l}-0.072 \\
(0.037)\end{array}$ & $\begin{array}{l}-0.038 \\
(0.046)\end{array}$ & $\begin{array}{l}-0.061 \\
(0.053)\end{array}$ \\
\hline $\mathrm{C}$ & $\begin{array}{l}-0.015 \\
(0.034)\end{array}$ & $\begin{array}{c}-0.024 \\
(0.035)\end{array}$ & $\begin{array}{c}0.001 \\
(0.044)\end{array}$ & $\begin{array}{l}-0.031 \\
(0.051)\end{array}$ \\
\hline $\mathrm{D}$ & $\begin{array}{l}-0.001 \\
(0.034)\end{array}$ & $\begin{array}{c}-0.014 \\
(0.036)\end{array}$ & $\begin{array}{c}0.010 \\
(0.044)\end{array}$ & $\begin{array}{l}-0.028 \\
(0.051)\end{array}$ \\
\hline Admissions Ratings Missing & $\begin{array}{l}-0.567 \\
(0.069)\end{array}$ & $\begin{array}{l}-0.562 \\
(0.070)\end{array}$ & $\begin{array}{l}-0.697 \\
(0.189)\end{array}$ & $\begin{array}{l}-0.659 \\
(0.192)\end{array}$ \\
\hline Recruited Athlete & $\begin{array}{c}0.082 \\
(0.017)\end{array}$ & $\begin{array}{c}0.080 \\
(0.018)\end{array}$ & $\begin{array}{c}0.101 \\
(0.024)\end{array}$ & $\begin{array}{c}0.105 \\
(0.028)\end{array}$ \\
\hline African-American & $\begin{array}{l}-0.375 \\
(0.018)\end{array}$ & $\begin{array}{l}-0.373 \\
(0.018)\end{array}$ & $\begin{array}{l}-0.379 \\
(0.023)\end{array}$ & $\begin{array}{l}-0.374 \\
(0.026)\end{array}$ \\
\hline Latino & $\begin{array}{l}-0.276 \\
(0.029)\end{array}$ & $\begin{array}{c}-0.278 \\
(0.031)\end{array}$ & $\begin{array}{l}-0.262 \\
(0.038)\end{array}$ & $\begin{array}{l}-0.279 \\
(0.044)\end{array}$ \\
\hline
\end{tabular}




\begin{tabular}{lcccc} 
Mexican & -0.309 & -0.314 & -0.323 & -0.340 \\
Other Hispanic & $(0.024)$ & $(0.025)$ & $(0.030)$ & $(0.035)$ \\
& -0.117 & -0.125 & -0.067 & -0.098 \\
Native American & $(0.044)$ & $(0.045)$ & $(0.051)$ & $(0.056)$ \\
& -0.156 & -0.159 & -0.174 & -0.188 \\
Asian & $(0.049)$ & $(0.051)$ & $(0.056)$ & $(0.063)$ \\
& -0.050 & -0.054 & -0.040 & -0.045 \\
Census Division Dummies Included' & $(0.014)$ & $(0.015)$ & $(0.017)$ & $(0.020)$ \\
& Yes & Yes & Yes & Yes \\
Number of Observations & & & & \\
Log Likelihood & 12749 & 11799 & 7700 & 5798 \\
Base Probability & -7825.920 & -7214.539 & -4754.616 & -3549.307 \\
\hline \hline
\end{tabular}

Notes: See notes to Table 4.

Includes only regular admission U.S. citizens 
Table 6:

Probit Analysis of Enrollment Decision at NEU among Minorities

\begin{tabular}{|c|c|c|c|c|c|c|}
\hline & \multicolumn{5}{|c|}{ Regular Admission U.S. Citizens } & \multirow[b]{2}{*}{$\begin{array}{l}\text { Reintroduce } \\
\text { Early } \\
\text { Applicants } \\
\text { (6) }\end{array}$} \\
\hline & $\begin{array}{c}\text { No Controls } \\
\text { (1) }\end{array}$ & $\begin{array}{c}\text { Add Student } \\
\text { Characteristics } \\
\text { (2) }\end{array}$ & $\begin{array}{l}\text { Add Race } \\
\text { (3) }\end{array}$ & $\begin{array}{l}\text { Add Middle- } \\
\text { Income } \\
\text { Controls } \\
\text { (4) }\end{array}$ & $\begin{array}{l}\text { Allow for } \\
\text { Class } \\
\text { Effects } \\
\text { (5) }\end{array}$ & \\
\hline Low-income & $\begin{array}{c}0.051 \\
(0.023)\end{array}$ & $\begin{array}{l}-0.084 \\
(0.026)\end{array}$ & $\begin{array}{l}-0.092 \\
(0.026)\end{array}$ & $\begin{array}{l}-0.115 \\
(0.030)\end{array}$ & $\begin{array}{l}-0.145 \\
(0.076)\end{array}$ & $\begin{array}{l}-0.101 \\
(0.071)\end{array}$ \\
\hline Program & $\begin{array}{c}0.054 \\
(0.022)\end{array}$ & $\begin{array}{c}0.116 \\
(0.024)\end{array}$ & $\begin{array}{c}0.118 \\
(0.024)\end{array}$ & $\begin{array}{c}0.108 \\
(0.027)\end{array}$ & & \\
\hline Program * Low-income & $\begin{array}{c}0.098 \\
(0.049)\end{array}$ & $\begin{array}{c}0.089 \\
(0.051)\end{array}$ & $\begin{array}{c}0.082 \\
(0.051)\end{array}$ & $\begin{array}{c}0.090 \\
(0.052)\end{array}$ & & \\
\hline Net program effect & & & & & $\begin{array}{l}0.081 \\
(0.052)\end{array}$ & $\begin{array}{c}0.100 \\
(0.049)\end{array}$ \\
\hline $\begin{array}{l}\text { Financial Aid Award } / 10^{3} \\
\text { (\$1999) }\end{array}$ & & $\begin{array}{c}0.008 \\
(0.001)\end{array}$ & $\begin{array}{c}0.008 \\
(0.001)\end{array}$ & $\begin{array}{c}0.009 \\
(0.001)\end{array}$ & $\begin{array}{l}0.008 \\
(0.001)\end{array}$ & $\begin{array}{c}0.007 \\
(0.001)\end{array}$ \\
\hline Female & & $\begin{array}{c}0.006 \\
(0.018)\end{array}$ & $\begin{array}{c}0.010 \\
(0.018)\end{array}$ & $\begin{array}{c}0.010 \\
(0.018)\end{array}$ & $\begin{array}{l}0.006 \\
(0.018)\end{array}$ & $\begin{array}{c}0.002 \\
(0.017)\end{array}$ \\
\hline Alumni Child & & $\begin{array}{c}0.157 \\
(0.074)\end{array}$ & $\begin{array}{c}0.155 \\
(0.074)\end{array}$ & $\begin{array}{l}0.156 \\
(0.074)\end{array}$ & $\begin{array}{c}0.149 \\
(0.074)\end{array}$ & $\begin{array}{c}0.126 \\
(0.065)\end{array}$ \\
\hline $\begin{array}{l}\text { Academic Rating: } \\
\text { A }\end{array}$ & & $\begin{array}{l}-0.533 \\
(0.081)\end{array}$ & $\begin{array}{l}-0.601 \\
(0.082)\end{array}$ & $\begin{array}{l}-0.605 \\
(0.083)\end{array}$ & $\begin{array}{l}-0.674 \\
(0.084)\end{array}$ & $\begin{array}{l}-0.644 \\
(0.076)\end{array}$ \\
\hline $\mathrm{B}$ & & $\begin{array}{l}-0.474 \\
(0.070)\end{array}$ & $\begin{array}{l}-0.500 \\
(0.071)\end{array}$ & $\begin{array}{l}-0.504 \\
(0.071)\end{array}$ & $\begin{array}{l}-0.574 \\
(0.073)\end{array}$ & $\begin{array}{l}-0.587 \\
(0.066)\end{array}$ \\
\hline C & & $\begin{array}{l}-0.359 \\
(0.069)\end{array}$ & $\begin{array}{l}-0.364 \\
(0.069)\end{array}$ & $\begin{array}{l}-0.368 \\
(0.069)\end{array}$ & $\begin{array}{l}-0.434 \\
(0.071)\end{array}$ & $\begin{array}{l}-0.455 \\
(0.065)\end{array}$ \\
\hline $\mathrm{D}$ & & $\begin{array}{l}-0.199 \\
(0.069)\end{array}$ & $\begin{array}{l}-0.197 \\
(0.069)\end{array}$ & $\begin{array}{l}-0.200 \\
(0.070)\end{array}$ & $\begin{array}{l}-0.243 \\
(0.071)\end{array}$ & $\begin{array}{l}-0.258 \\
(0.064)\end{array}$ \\
\hline $\begin{array}{l}\text { Non-academic Rating: } \\
\text { A }\end{array}$ & & $\begin{array}{l}-0.177 \\
(0.119)\end{array}$ & $\begin{array}{l}-0.218 \\
(0.122)\end{array}$ & $\begin{array}{l}-0.221 \\
(0.122)\end{array}$ & $\begin{array}{l}-0.226 \\
(0.124)\end{array}$ & $\begin{array}{l}-0.168 \\
(0.103)\end{array}$ \\
\hline $\mathrm{B}$ & & $\begin{array}{l}-0.076 \\
(0.053)\end{array}$ & $\begin{array}{l}-0.076 \\
(0.053)\end{array}$ & $\begin{array}{l}-0.076 \\
(0.054)\end{array}$ & $\begin{array}{l}-0.093 \\
(0.055)\end{array}$ & $\begin{array}{l}-0.078 \\
(0.050)\end{array}$ \\
\hline C & & $\begin{array}{l}-0.041 \\
(0.046)\end{array}$ & $\begin{array}{l}-0.036 \\
(0.047)\end{array}$ & $\begin{array}{l}-0.036 \\
(0.047)\end{array}$ & $\begin{array}{l}-0.046 \\
(0.047)\end{array}$ & $\begin{array}{l}-0.043 \\
(0.043)\end{array}$ \\
\hline $\mathrm{D}$ & & $\begin{array}{l}-0.029 \\
(0.046)\end{array}$ & $\begin{array}{l}-0.017 \\
(0.046)\end{array}$ & $\begin{array}{l}-0.018 \\
(0.046)\end{array}$ & $\begin{array}{l}-0.016 \\
(0.046)\end{array}$ & $\begin{array}{l}-0.024 \\
(0.042)\end{array}$ \\
\hline Admissions Ratings Missing & & $\begin{array}{l}-0.050 \\
(0.304)\end{array}$ & $\begin{array}{l}-0.029 \\
(0.308)\end{array}$ & $\begin{array}{l}-0.040 \\
(0.308)\end{array}$ & $\begin{array}{l}-0.077 \\
(0.307)\end{array}$ & $\begin{array}{l}-0.718 \\
(0.136)\end{array}$ \\
\hline
\end{tabular}




\begin{tabular}{|c|c|c|c|c|c|}
\hline Recruited Athlete & $\begin{array}{c}0.199 \\
(0.049)\end{array}$ & $\begin{array}{c}0.189 \\
(0.049)\end{array}$ & $\begin{array}{c}0.186 \\
(0.049)\end{array}$ & $\begin{array}{c}0.183 \\
(0.050)\end{array}$ & $\begin{array}{c}0.130 \\
(0.045)\end{array}$ \\
\hline Latino & & $\begin{array}{c}0.117 \\
(0.030)\end{array}$ & $\begin{array}{c}0.116 \\
(0.030)\end{array}$ & $\begin{array}{c}0.120 \\
(0.030)\end{array}$ & $\begin{array}{c}0.115 \\
(0.029)\end{array}$ \\
\hline Mexican & & $\begin{array}{c}0.063 \\
(0.027)\end{array}$ & $\begin{array}{c}0.063 \\
(0.027)\end{array}$ & $\begin{array}{c}0.068 \\
(0.027)\end{array}$ & $\begin{array}{c}0.070 \\
(0.025)\end{array}$ \\
\hline Other Hispanic & & $\begin{array}{c}0.243 \\
(0.046)\end{array}$ & $\begin{array}{c}0.244 \\
(0.046)\end{array}$ & $\begin{array}{c}0.258 \\
(0.046)\end{array}$ & $\begin{array}{c}0.211 \\
(0.037)\end{array}$ \\
\hline Native American & & $\begin{array}{c}0.202 \\
(0.048)\end{array}$ & $\begin{array}{c}0.201 \\
(0.048)\end{array}$ & $\begin{array}{c}0.206 \\
(0.048)\end{array}$ & $\begin{array}{c}0.163 \\
(0.046)\end{array}$ \\
\hline Middle Income & & & $\begin{array}{c}-(0.057) \\
(0.032)\end{array}$ & $\begin{array}{l}(0.018) \\
(0.021)\end{array}$ & \\
\hline Middle Income * Program & & & $\begin{array}{l}(0.049) \\
(0.061)\end{array}$ & $\begin{array}{l}(0.024) \\
(0.044)\end{array}$ & \\
\hline \multicolumn{6}{|l|}{ Graduating Class } \\
\hline 1992 & & & & -0.058 & -0.080 \\
\hline 1993 & & & & $\begin{array}{l}(0.051) \\
-0.131 \\
(0.049)\end{array}$ & $\begin{array}{c}(0.047) \\
-0.170 \\
(0.046)\end{array}$ \\
\hline 1994 & & & & $\begin{array}{l}-0.063 \\
(0.049)\end{array}$ & $\begin{array}{l}-0.068 \\
(0.045)\end{array}$ \\
\hline 1995 & & & & $\begin{array}{l}-0.115 \\
(0.050)\end{array}$ & $\begin{array}{l}-0.100 \\
(0.045)\end{array}$ \\
\hline 1996 & & & & $\begin{array}{l}-0.112 \\
(0.050)\end{array}$ & $\begin{array}{l}-0.103 \\
(0.045)\end{array}$ \\
\hline 1997 & & & & $\begin{array}{l}-0.095 \\
(0.047)\end{array}$ & $\begin{array}{l}-0.084 \\
(0.044)\end{array}$ \\
\hline 1998 & & & & $\begin{array}{l}-0.056 \\
(0.048)\end{array}$ & $\begin{array}{l}-0.030 \\
(0.045)\end{array}$ \\
\hline 2000 & & & & $\begin{array}{c}0.045 \\
(0.051)\end{array}$ & -- \\
\hline 2001 & & & & $\begin{array}{c}0.014 \\
(0.050)\end{array}$ & $\begin{array}{l}-0.066 \\
(0.050)\end{array}$ \\
\hline 2002 & & & & $\begin{array}{c}0.071 \\
(0.049)\end{array}$ & $\begin{array}{c}0.005 \\
(0.049)\end{array}$ \\
\hline 2003 & & & & $\begin{array}{c}0.066 \\
(0.051)\end{array}$ & $\begin{array}{c}0.006 \\
(0.051)\end{array}$ \\
\hline 2004 & & & & $\begin{array}{c}0.064 \\
(0.049)\end{array}$ & $\begin{array}{l}-0.002 \\
(0.049)\end{array}$ \\
\hline \multicolumn{6}{|c|}{ Low-income * Graduating Class } \\
\hline 1992 & & & & $\begin{array}{c}0.204 \\
(0.107)\end{array}$ & $\begin{array}{c}0.137 \\
(0.098)\end{array}$ \\
\hline 1993 & & & & $\begin{array}{c}0.034 \\
(0.102)\end{array}$ & $\begin{array}{c}0.075 \\
(0.094)\end{array}$ \\
\hline 1994 & & & & 0.214 & 0.179 \\
\hline
\end{tabular}




\section{6}

$-0.170$

1996

1997

1998

2000

2001

2002

2003

2004

Applied early action/decision

Early decision year

\begin{tabular}{lcccccc} 
Census Division dummies & No & Yes & Yes & Yes & Yes & Yes \\
& & & & & & \\
Log Likelihood & -2375.878 & -2205.500 & -2180.132 & -2178.570 & -2148.199 & -2585.493 \\
Number of Observations & 3523 & 3523 & 3523 & 3523 & 3523 & 4442 \\
Base Probability & 0.415 & 0.409 & 0.407 & 0.407 & 0.406 & 0.460 \\
\hline \hline
\end{tabular}

Notes: Standard errors are in parentheses. Coefficients reported are marginal effects.

The omitted race category is African-American.

The net program effect in columns (5) and (6) is calculated as the average of the class * low-income interactions after the policy change (2002-2004) minus the average of the interactions before the policy change.

The base probability is the predicted probability of enrollment evaluated at the mean student characteristics.

Class of 2000 effect is omitted in column (6) because of colinearity with program and early decision year 
Table 8: Probit Analysis of Student Interest in NEU

\begin{tabular}{lccccc}
\hline \hline & \multicolumn{2}{c}{ All Test-takers } & & \multicolumn{2}{c}{ Minority Test-takers } \\
\cline { 2 - 3 } \cline { 6 - 6 } & $(1)$ & $(2)$ & & $(3)$ & $(4)$ \\
\hline & & & & & \\
Low-income & -1.344 & 0.201 & & -0.976 & 0.157 \\
& $(0.025)$ & $(0.016)$ & & $(0.034)$ & $(0.020)$ \\
Took SAT after Jan. 1998 & -0.155 & -0.175 & & -0.044 & -0.265 \\
& $(0.024)$ & $(0.040)$ & & $(0.034)$ & $(0.060)$ \\
Took SAT after Jan. 1998 & 0.003 & 0.051 & & -0.090 & -0.002 \\
$\quad$ * Low-income & $(0.049)$ & $(0.020)$ & & $(0.049)$ & $(0.025)$ \\
& & & & \\
Includes other covariates? & No & Yes & & No & Yes \\
Log-likelihood & -319570 & -244776 & & -94755 & -77103 \\
Number of observations & 3031573 & 3031573 & & 1125231 & 1125231 \\
\hline \hline
\end{tabular}

Notes:

Marginal effects $\times 100$ reported. Standard errors in parentheses.

Data from College Board. See text for description.

Dependent variable in all specifications is student submitted SAT scores to NEU.

Covariates are those listed in Appendix Table 1.

Weighted by weights generated by the College Board 
Figure 1: Yield Rates among Regular Decision U.S. Citizens

All Students:

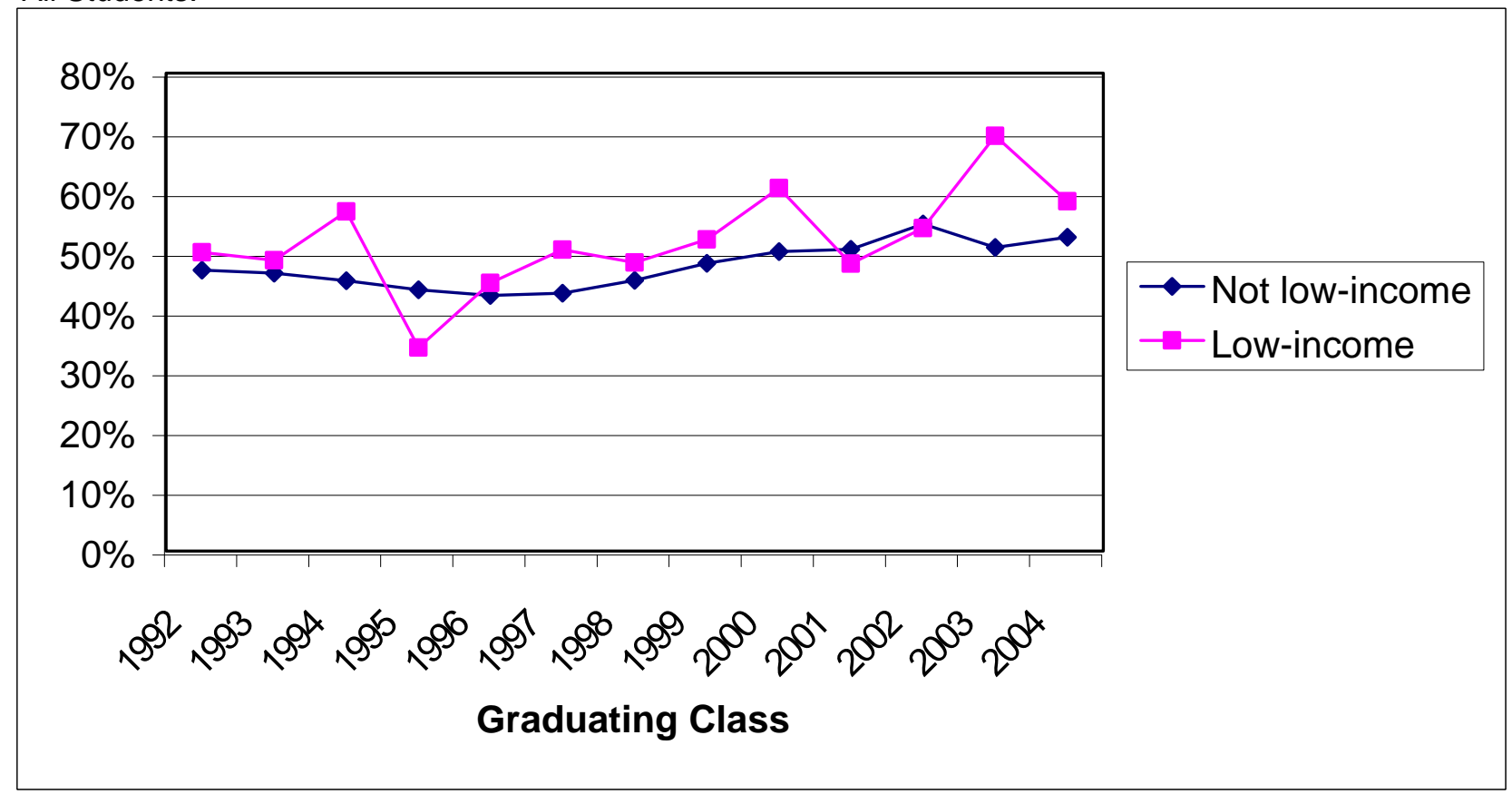

Minorities:

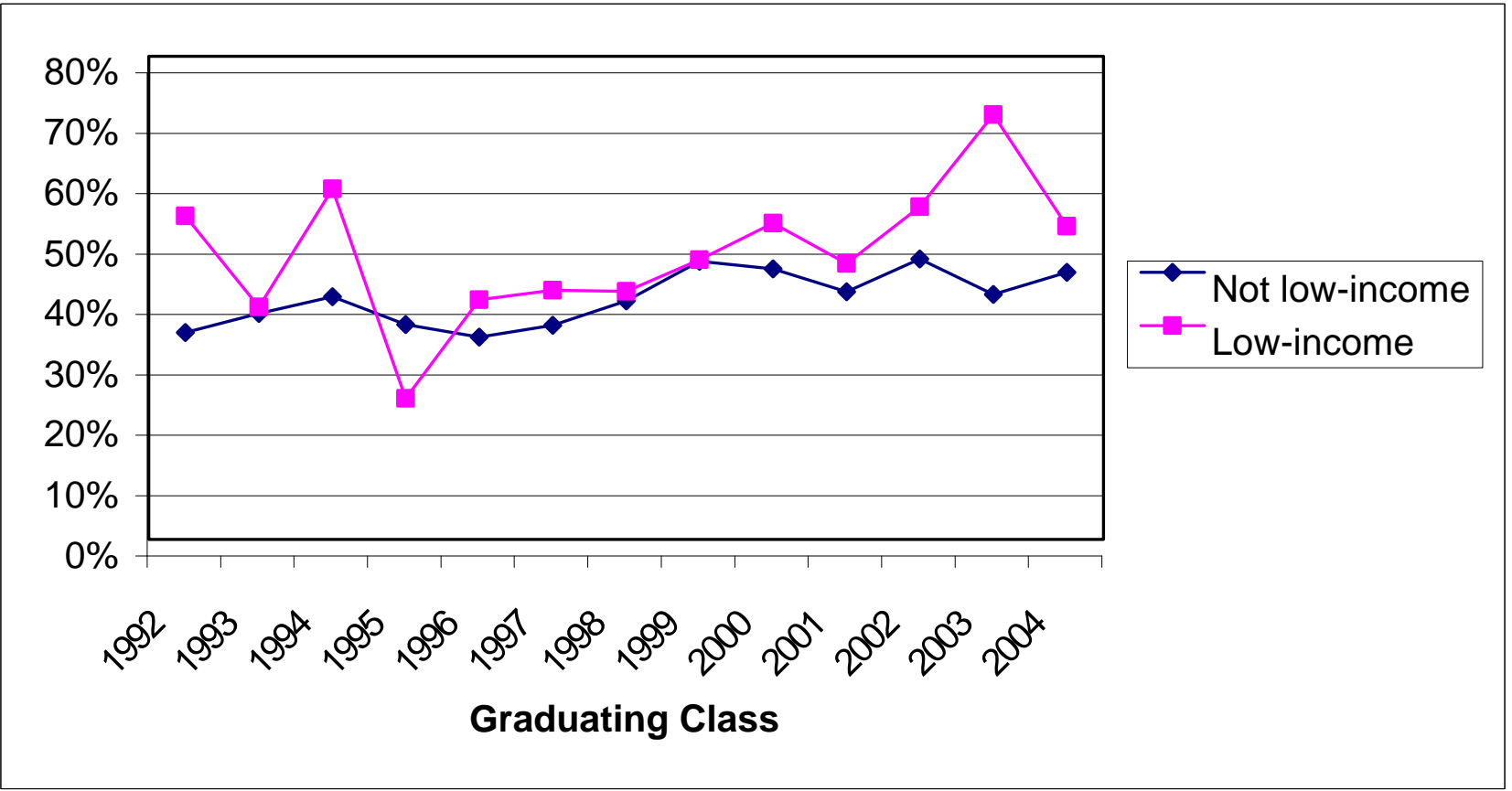

Notes:

Yield rate is the percentage of admitted students who enroll.

These calculations show only U.S. citizens who did not apply early action or early decision.

Minority is defined as Black, Hispanic, or Native American (self-reported). 
Figure 2: Regression-Adjusted Yield Rates for Regular Decision U.S. Citizens

Controlling for student characteristics and total aid award

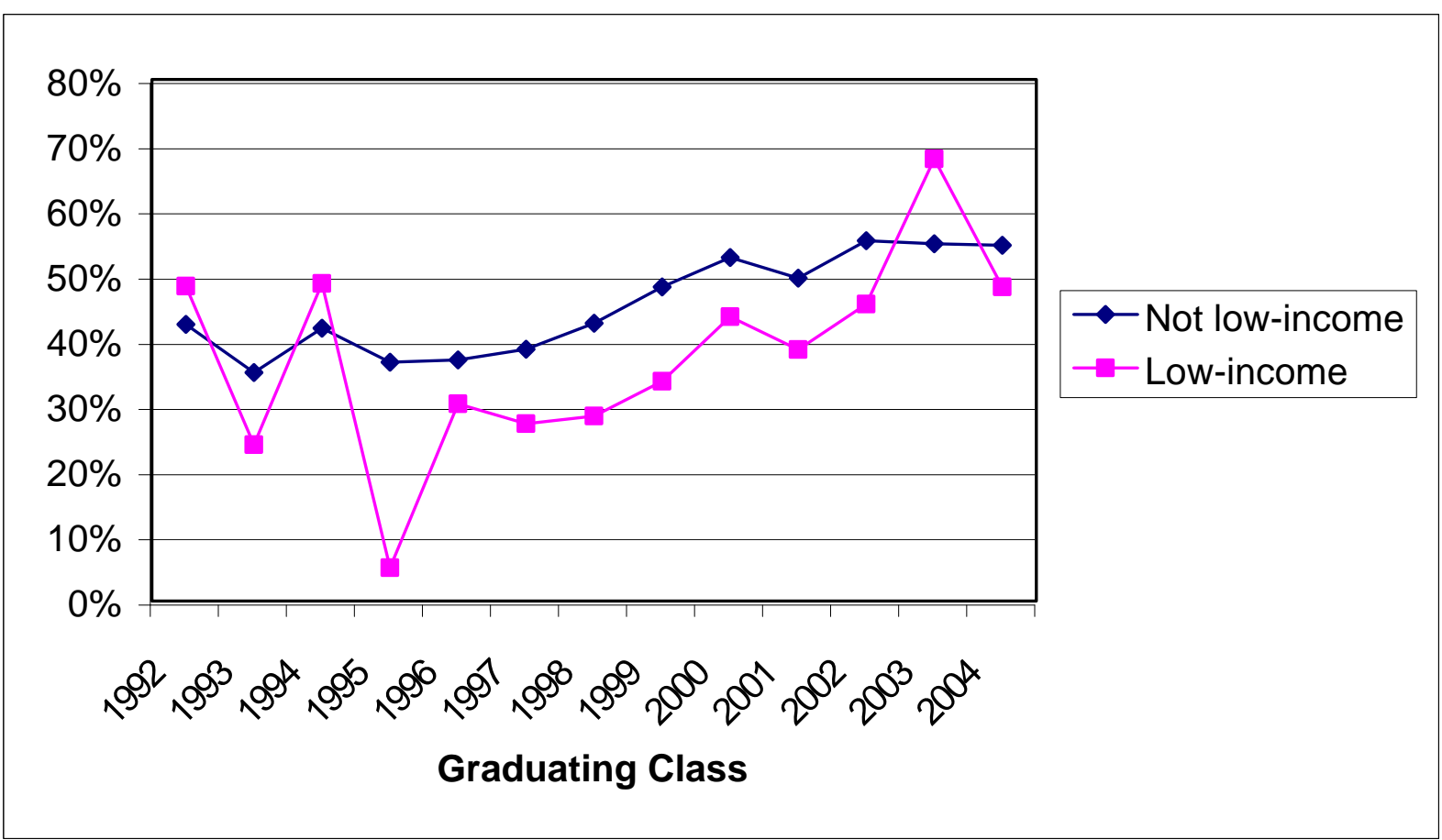

National-median based low-income codings, 1999 as base year Low income rate for each class year computed as sum of low-income coefficient, class dummy coefficient, class * low-income interaction, and base yield (1999 not low-income).

Not low-income rate for each class year computed as sum of class dummy coefficient and base yield (1999 not low-income).

Yield rates adjusted using the marginal effects probit regression reported in Table 4 column 3 
Figure 3: Yield Rates at Similar Universities

For minorities and for all students at seven other Northeastern universities
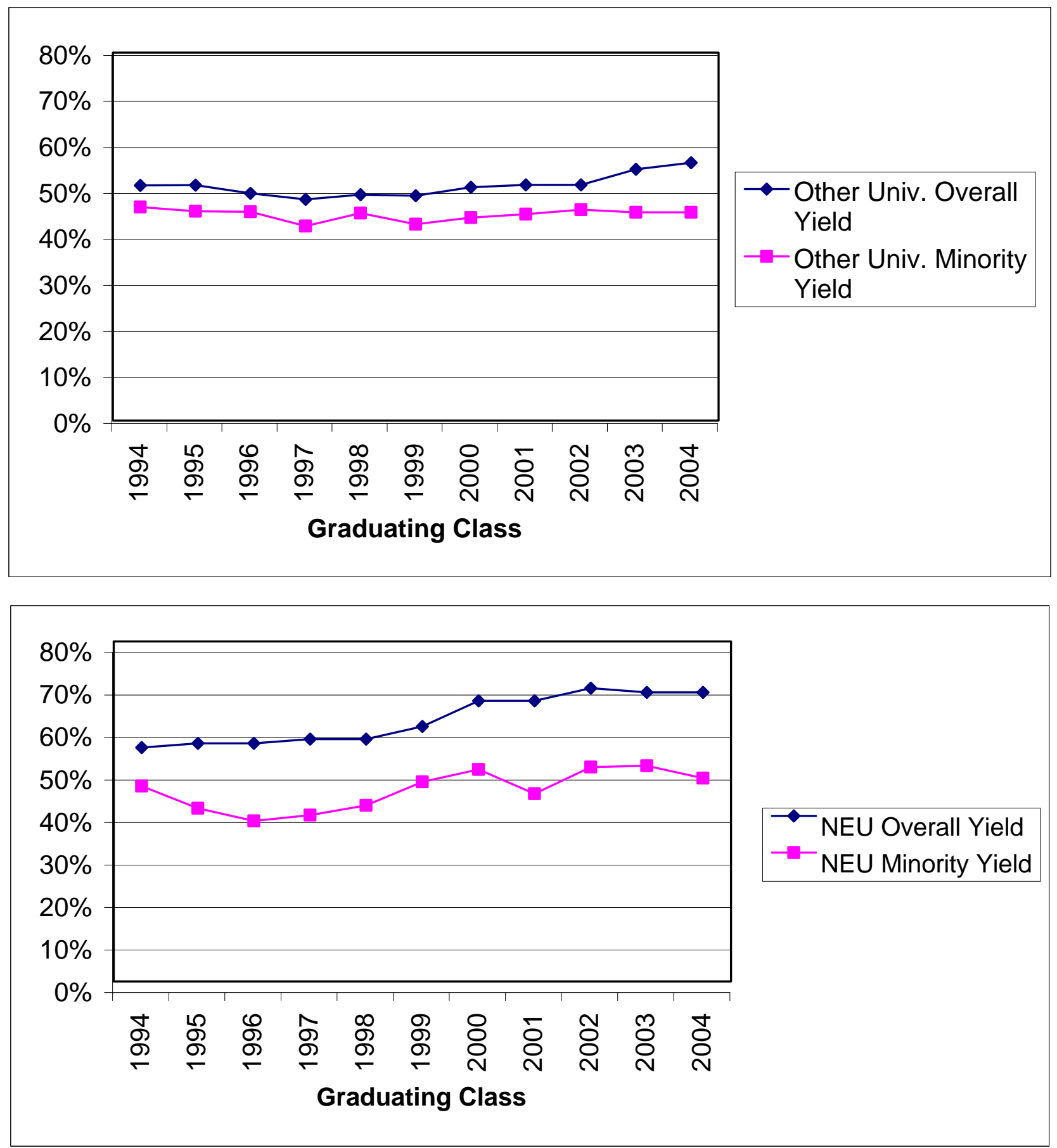

Both panels, including NEU, from data provided by the Consortium on Financing Higher Education.

NEU data in this figure are not comparable to previous figures due to the inclusion of early admissions and foreign students, included here for comparability with COFHE data from other universities.

Minority refers to African-American, Hispanic, and Native American students. 
Figure 4: Average Grant Aid per Grant Recipient

For all students at NEU and seven other Northeastern universities

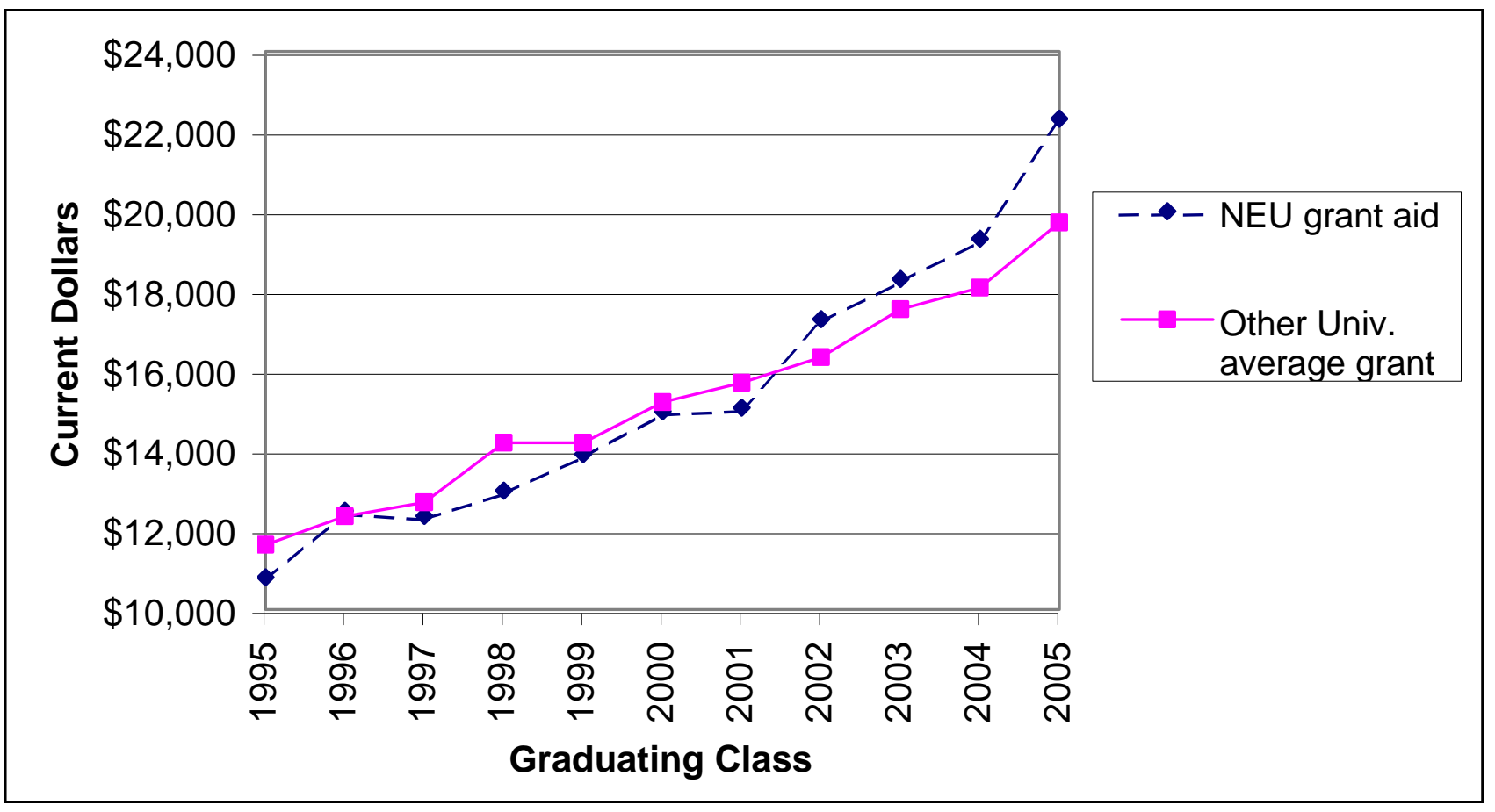

Notes: Data from COFHE. See text for description. 
Appendix Table 1:

Means of Student Characteristics -- College Board Data

\begin{tabular}{|c|c|c|c|c|c|c|}
\hline & \multicolumn{3}{|c|}{ Expressed interest in NEU } & \multicolumn{3}{|c|}{ Did not express interest in NEU } \\
\hline & All & $\begin{array}{l}\text { Not low- } \\
\text { income }\end{array}$ & Low-income & All & $\begin{array}{l}\text { Not low- } \\
\text { income }\end{array}$ & Low-income \\
\hline Plan to apply for financial aid & 0.700 & 0.644 & 0.938 & 0.762 & 0.693 & 0.904 \\
\hline Family Income in $\$ 1000$ & 80.31 & 93.11 & 26.17 & 60.76 & 77.88 & 25.54 \\
\hline Female & 0.469 & 0.460 & 0.506 & 0.554 & 0.535 & 0.592 \\
\hline Recentered SAT I Math & 660.3 & 673.7 & 603.6 & 518.4 & 536.4 & 481.3 \\
\hline Recentered SAT I Verbal & 652.3 & 665.2 & 597.6 & 517.6 & 534.1 & 483.7 \\
\hline Don't know if apply for aid & 0.175 & 0.204 & 0.052 & 0.158 & 0.197 & 0.080 \\
\hline Grade 12 junior ROTC & 0.007 & 0.005 & 0.013 & 0.012 & 0.009 & 0.019 \\
\hline Expect to play a sport & 0.860 & 0.877 & 0.786 & 0.779 & 0.809 & 0.716 \\
\hline Income missing & 0.124 & 0.153 & 0.000 & 0.107 & 0.159 & 0.000 \\
\hline Financial aid missing & 0.009 & 0.011 & 0.001 & 0.008 & 0.011 & 0.002 \\
\hline Sport missing & 0.072 & 0.062 & 0.114 & 0.111 & 0.094 & 0.144 \\
\hline After 1998 & 0.363 & 0.362 & 0.365 & 0.372 & 0.371 & 0.375 \\
\hline Northeast & 0.075 & 0.080 & 0.051 & 0.088 & 0.092 & 0.080 \\
\hline Mid-Atlantic & 0.352 & 0.341 & 0.396 & 0.219 & 0.214 & 0.228 \\
\hline West North Central & 0.029 & 0.030 & 0.023 & 0.017 & 0.020 & 0.011 \\
\hline South-Atlantic & 0.176 & 0.178 & 0.169 & 0.240 & 0.233 & 0.256 \\
\hline East North Central & 0.094 & 0.100 & 0.067 & 0.101 & 0.112 & 0.079 \\
\hline Mountain & 0.031 & 0.031 & 0.034 & 0.036 & 0.039 & 0.032 \\
\hline East South Central & 0.021 & 0.022 & 0.019 & 0.017 & 0.019 & 0.013 \\
\hline West South Central & 0.072 & 0.067 & 0.094 & 0.107 & 0.101 & 0.121 \\
\hline State Missing & 0.000 & 0.000 & 0.000 & 0.000 & 0.000 & 0.000 \\
\hline \multicolumn{7}{|l|}{ Father's education } \\
\hline Grade school & 0.012 & 0.004 & 0.042 & 0.020 & 0.006 & 0.049 \\
\hline Some high school & 0.018 & 0.007 & 0.064 & 0.043 & 0.019 & 0.092 \\
\hline High school diploma & 0.077 & 0.047 & 0.202 & 0.193 & 0.141 & 0.300 \\
\hline Business school & 0.026 & 0.020 & 0.053 & 0.049 & 0.043 & 0.062 \\
\hline Some college & 0.087 & 0.070 & 0.158 & 0.150 & 0.141 & 0.169 \\
\hline Associate's degree & 0.031 & 0.026 & 0.050 & 0.062 & 0.062 & 0.061 \\
\hline Bachelor's degree & 0.198 & 0.203 & 0.180 & 0.205 & 0.244 & 0.126 \\
\hline Some graduate school & 0.059 & 0.063 & 0.044 & 0.042 & 0.052 & 0.022 \\
\hline Graduate degree & 0.462 & 0.533 & 0.162 & 0.193 & 0.256 & 0.064 \\
\hline \multicolumn{7}{|l|}{ Mother's education } \\
\hline Grade school & 0.011 & 0.004 & 0.040 & 0.018 & 0.005 & 0.045 \\
\hline Some high school & 0.018 & 0.007 & 0.064 & 0.036 & 0.015 & 0.079 \\
\hline High school diploma & 0.103 & 0.075 & 0.223 & 0.226 & 0.184 & 0.312 \\
\hline Business school & 0.029 & 0.023 & 0.054 & 0.052 & 0.045 & 0.065 \\
\hline Some college & 0.114 & 0.099 & 0.179 & 0.174 & 0.163 & 0.196 \\
\hline Associate's degree & 0.061 & 0.055 & 0.084 & 0.091 & 0.092 & 0.088 \\
\hline Bachelor's degree & 0.261 & 0.278 & 0.189 & 0.189 & 0.224 & 0.117 \\
\hline Some graduate school & 0.083 & 0.090 & 0.050 & 0.052 & 0.064 & 0.028 \\
\hline Graduate degree & 0.296 & 0.342 & 0.104 & 0.134 & 0.174 & 0.051 \\
\hline Father's ed missing & 0.030 & 0.027 & 0.045 & 0.042 & 0.036 & 0.054 \\
\hline Mother's ed missing & 0.023 & 0.026 & 0.014 & 0.027 & 0.032 & 0.018 \\
\hline Number of observations & 61476 & 47170 & 14306 & 2970097 & 1834579 & 1135518 \\
\hline
\end{tabular}

Note: Data from College Board. See text for description 

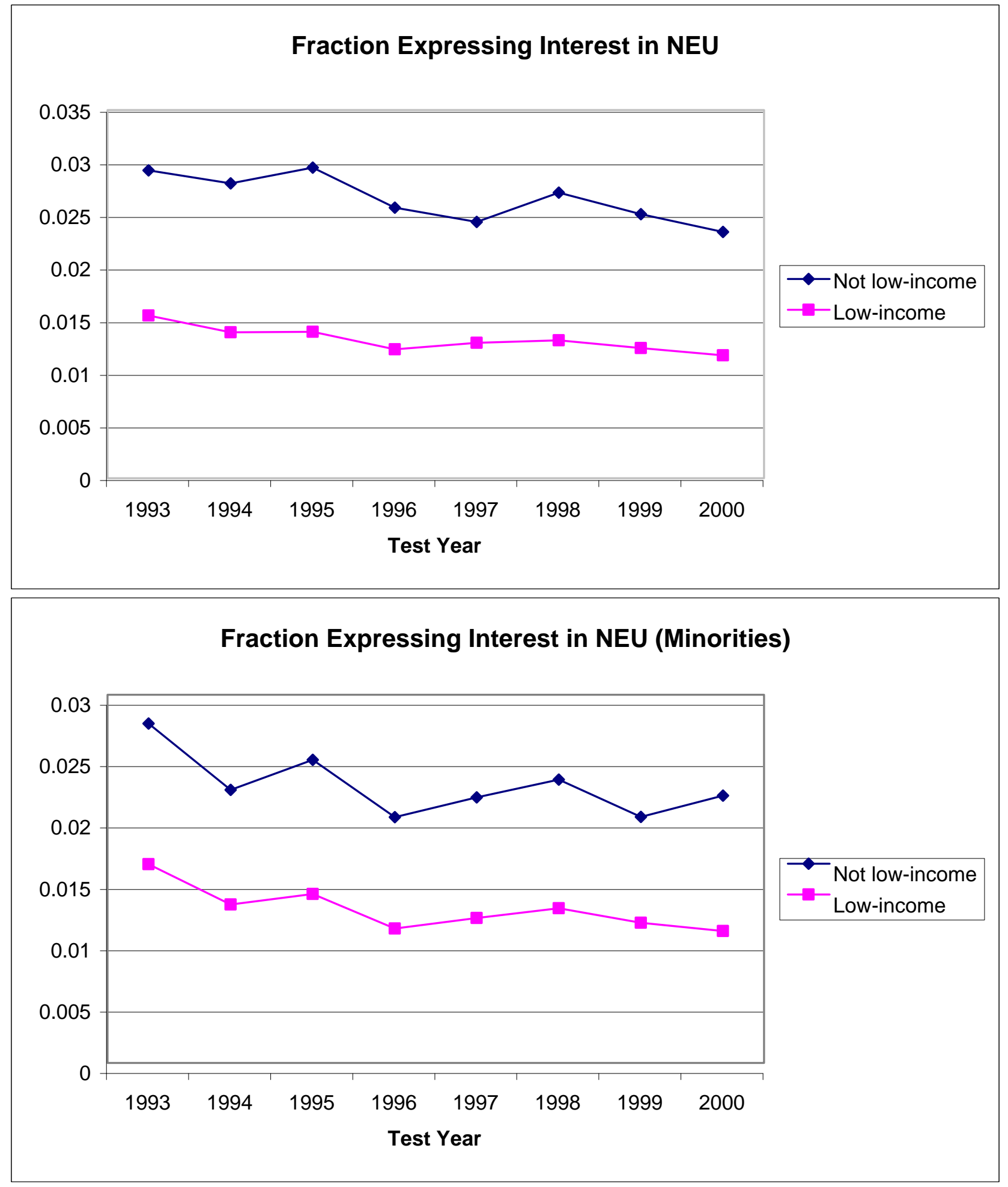

Chart shows fraction of students taking SAT in each year who sent their test scores to NEU.

Data from the College Board. See text for more complete description. 